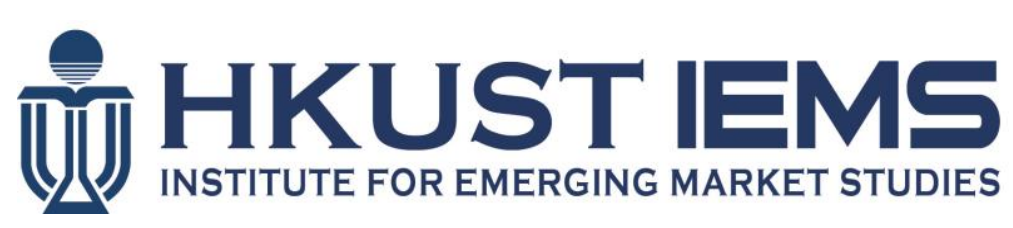

\title{
Post-Earnings-Announcement Drift in Global Markets: Evidence from an Information Shock
}

\author{
Mingyi HUNG, Xi LI, Shiheng WANG
}

HKUST IEMS Working Paper No. 2015-17

March 2015

\begin{abstract}
HKUST IEMS working papers are distributed for discussion and comment purposes. The views expressed in these papers are those of the authors and do not necessarily represent the views of HKUST IEMS.
\end{abstract}

More HKUST IEMS working papers are available at: http://iems.ust.hk/WP 
Post-Earnings-Announcement Drift in Global Markets: Evidence from an Information Shock

Mingyi HUNG, Xi LI, Shiheng WANG

HKUST IEMS Working Paper No. 2015-17

March 2015

\begin{abstract}
We investigate whether and how an exogenous and unprecedented improvement in nonU.S. firms' financial reporting quality affects post-earnings-announcement drift (PEAD). We find that PEAD declines after the information shock, and this decrease is more pronounced for firms with fewer concurrent earnings announcements, greater institutional holdings, and lower limits to arbitrage. In addition, the decrease in PEAD is driven by firms with greater changes in financial reporting, an increase in analyst forecast accuracy and institutional ownership, and a decrease in limits to arbitrage. These findings support the mispricing explanation of PEAD, in particular the limited attention hypothesis, in an international setting.
\end{abstract}

\title{
Author's contact information
}

Mingyi Hung

Department of Accounting

The Hong Kong University of Science and Technology

Hong Kong

E: acmy@ust.hk

Tel: +85223587577

Xi Li

Department of Accounting

The Hong Kong University of Science and Technology

Hong Kong

Shiheng Wang

Department of Accounting

The Hong Kong University of Science and Technology

Hong Kong 


\section{Post-Earnings-Announcement Drift in Global Markets: Evidence from an Information Shock}

\section{Mingyi Hung}

Hong Kong University of Science and Technology

\section{Xi Li}

Hong Kong University of Science and Technology

Shiheng Wang

Hong Kong University of Science and Technology

We thank the following for their helpful comments: Bing Han, David Hirshleifer (the editor), Chuan Yang Hwang, Grace Pownall, Katherine Schipper, Nancy Su, John Wei, three anonymous referees, and workshop participants at the Asian Finance Association 2013 conference, the Hong Kong Polytechnic University 2013 Mini Conference on Cross-Listings, the Hong Kong University of Science and Technology, the National Taiwan University, and the University of Hong Kong. Send correspondence to Mingyi Hung, Department of Accounting, Hong Kong University of Science and Technology, Clear Water Bay, Kowloon, Hong Kong; telephone: +852 2358 7577. Email: acmy@ust.hk. 
We investigate whether and how an exogenous and unprecedented improvement in non-U.S. firms' financial reporting quality affects post-earnings-announcement drift (PEAD). We find that PEAD declines after the information shock, and this decrease is more pronounced for firms with fewer concurrent earnings announcements, greater institutional holdings, and lower limits to arbitrage. In addition, the decrease in PEAD is driven by firms with greater changes in financial reporting, an increase in analyst forecast accuracy and institutional ownership, and a decrease in limits to arbitrage. These findings support the mispricing explanation of PEAD, in particular the limited attention hypothesis, in an international setting. 


\section{Introduction}

Post-earnings-announcement drift (PEAD), defined as a significantly positive relation between currently announced earnings surprises and subsequent stock returns, is the focus of a large body of literature in the U.S. and one of the most robust anomalies that challenge the efficient market paradigm (Bernard and Thomas 1989, 1990; Fama 1998). The international evidence, however, is limited and inconclusive. The purpose of our study is to fill this void and investigate the impact of an exogenous and unprecedented improvement in non-U.S. firms' financial reporting quality on changes in PEAD, thereby providing fresh evidence on the existence and explanations of PEAD and improving our understanding of market efficiency worldwide.

Prior theoretical work and empirical studies using U.S. data suggest that PEAD is driven by mispricing, characterized as investors' underreaction to earnings news due to limited attention or other psychological biases (Bernard and Thomas 1989, 1990; Barberis, Shleifer, and Vishny 1998; Daniel, Hirshleifer, and Subrahmanyam 1998), and limits to arbitrage (Shleifer and Vishny 1997). Consistent with this perspective, prior research finds that PEAD is greater for earnings announcements on Friday, when investor inattention is more likely, and on days with more concurrent earnings announcements to distract investors (DellaVigna and Pollet 2009; Hirshleifer, Lim, and Teoh 2009). This research also finds that PEAD is stronger for firms with greater limits to arbitrage, suggesting that impediments such as arbitrage risks and transaction costs prevent investors from acting quickly on new information (Mendenhall 2004).

The international evidence regarding PEAD, however, is puzzling. While some studies find that PEAD exists in countries such as the U.K., Spain, and New Zealand (Hew, Skerratt, Strong, and Walker 1996; Forner and Sanabria 2010; Truong 2010, respectively), other studies find little evidence of PEAD in countries such as Belgium and Singapore (Van Huffel, Joos, and Ooghe 1996; Ariff, Loh, and Chew 1997, respectively). In addition, in the course of investigating the 
validity of using anomaly measures, such as PEAD, to compare market efficiency in emerging and developed markets, Griffin, Kelly, and Nardari (2010) find that PEAD is prevalent throughout the world markets but is not correlated with common measures of institutional environments including information environments or transaction costs. Since these institutional factors are viewed as common building blocks of efficiency, the global findings regarding PEAD challenge our understanding of this phenomenon and its underlying sources.

One potential reason for the unclear portrait of PEAD that emerges in global studies is that PEAD is an equilibrium outcome of various factors that are jointly determined by a country's institutional environment, which can affect PEAD in opposite directions. ${ }^{1}$ An exogenous shock provides a natural setting that makes it possible to tackle this empirical challenge (Angrist and Krueger 2001). Specifically, since an exogenous information shock has a direct impact on one major driver of PEAD, uncertainty, we are able to test directional predictions about the effect of the shock on PEAD. By using a dramatic exogenous information shock with a difference-indifferences (DID) approach, we mitigate the identification issue and are thus better able to assess the relation between PEAD and its drivers in an international setting.

If PEAD is driven by investors' incomplete reactions to earnings news, we expect PEAD to decrease subsequent to increased financial reporting quality. ${ }^{2}$ This is because improved financial reporting quality reduces uncertainty and investors make fewer investment mistakes when uncertainty is lower and stocks are easier to value (Kumar 2009). In addition, owing to limited

1 For example, countries with better financial reporting environments usually are associated with lower limits to arbitrage and abundant levels of firm-specific news. While lower limits to arbitrage should lead to more complete processing of earnings news and therefore lower PEAD, abundant levels of firm-specific news (especially irrelevant signals unrelated to the firm making the earnings announcement) can exacerbate the problem of investors' limited attention and lead to higher PEAD.

2 We use the term "increased financial reporting quality" to represent two non-mutually exclusive concepts: (1) increased disclosure, defined as the revelation of facts and measurement issues, and (2) improved comparability, defined as the quality of information that enables users to identify similarities in and differences between two sets of economic phenomena (IASB 1989, 2008; Hong, Hung, and Lobo 2014). 
investor attention, firms with less distraction or greater institutional ownership should experience a greater reduction in PEAD when financial reporting quality improves. Specifically, limited attention impedes investor ability to process detailed financial statement information (Hirshleifer and Teoh 2003; Hirshleifer, Lim, and Teoh 2011). Since attention span and consequent learning ability are greater for investors with fewer distractions or more sophistication, such investors are better able to take advantage of the benefits of improved financial reporting quality. ${ }^{3}$ In addition, owing to limits to arbitrage, firms with lower transaction costs or arbitrage risks should also experience a greater reduction in PEAD when financial reporting quality improves, as investors can react more quickly and completely to new information about these stocks. Finally, prior research finds that improved financial reporting quality is associated with increased analyst forecast accuracy, increased foreign institutional ownership, and decreased limits to arbitrage (Healy and Palepu 2001). If these factors are the underlying channels through which improved financial reporting quality reduces PEAD, we expect a greater reduction in PEAD among firms with larger changes to their financial reporting, an increase in analyst forecast accuracy and institutional ownership, or a decrease in limits to arbitrage.

Our empirical setting takes advantage of the 2005 mandatory adoption of International Financial Reporting Standards (IFRS) worldwide. This information shock is one of the biggest events in the history of financial reporting, affecting thousands of companies worldwide. It thus offers a unique and powerful opportunity for testing our predictions for several reasons. First, since the shock is exogenous to individual firms, our results are not subject to endogeneity and selfselection concerns. Second, the shock allows us to use a DID research design by comparing the

3 While it is possible that firms with more distraction or lower institutional holdings may benefit more from the increased financial reporting quality because they have more room for improvement, this scenario biases against finding our predicted results. More importantly, we expect that distracted or unsophisticated investors are less likely to base their investment decisions on analyses of financial statements, and therefore the benefits of increased financial reporting quality are less likely to accrue to these types of investors. 
changes in PEAD for firms in adoption countries with the changes in PEAD for firms in nonadoption countries subsequent to the shock. This comparison of the time-series difference in PEAD for the treatment firms helps us identify the potential treatment effect of the information shock after controlling for largely time-invariant firm and country factors. Furthermore, our comparison of changes in PEAD for the treated versus untreated firms in our sample mitigates the influence of possible confounding factors such as changing economic conditions. Finally, the broad impact of this information shock facilitates a study of the roles of firm- and country-level characteristics in PEAD, allowing for a more in-depth understanding of the impact of financial reporting quality on PEAD in an international setting.

Our sample consists of 6,862 firm-year observations (1,921 firms) from 18 treatment countries that mandated IFRS adoption in 2005 as well as 14,258 firm-year observations (4,049 firms) from 12 benchmark countries that did not mandate adoption during our sample period. To reduce the effect of potentially confounding events, such as the 2008 financial crisis, we restrict our analysis to the two-year periods before and after the 2005 mandate.

Our multivariate regression analyses show that, subsequent to the information shock, PEAD weakens significantly in our treatment firms but does not change in our benchmark firms. Furthermore, we find that this reduction in PEAD among treatment countries is economically significant, representing a decrease of $2.75 \%$ of the quarterly abnormal returns generated by PEAD after the information shock. This finding is consistent with our prediction that increased financial reporting quality reduces uncertainty, which in turn allows investors to react more completely to earnings news.

To mitigate potential concerns regarding confounding events such as unrelated institutional changes or economic shocks, we perform a variety of sensitivity tests, including the use of 
alternative treatment samples, alternative benchmark samples, and different sample periods. ${ }^{4} \mathrm{We}$ also conduct robustness checks to address potential concerns regarding the comparability of our treatment and benchmark samples under the DID test. Using voluntary IFRS adopters (from the same countries as the treatment sample), 2003 and 2008 as the pseudo-adoption year during the pre-shock period (2001-2004) and the post-shock periods (2006-2009), and separate analyses for developed and emerging economies, we find similar results. Finally, using alternative definitions of earnings surprises and clustering methods, we again find our results remain qualitatively similar.

To further understand our results, we perform various cross-sectional analyses to corroborate the explanation that PEAD results from mispricing due to limited investor attention and limits to arbitrage. These analyses show that PEAD decreases more for firms with less distraction (as captured by concurrent earnings announcements), more sophisticated investors (as captured by institutional holdings), lower transaction costs (as captured by Amihud illiquidity), and fewer arbitrage risks (as captured by idiosyncratic volatility). Our evidence also shows that both limited attention and limits to arbitrage are important driving forces for PEAD and do not dominate each other.

In addition, we perform analyses examining the role of country-level institutions on PEAD. We find that PEAD decreases after improvements in financial reporting quality more so for firms in countries with greater capital market development, stronger rule of law, and less earnings management. Further, we find that distraction effects and arbitrage risks are important in developed markets while transaction costs are important in emerging markets in reducing PEAD after the information shock.

\footnotetext{
${ }^{4}$ Specifically, our results hold for using both European and non-European countries, countries with and without concurrent enforcement changes, non-2005 IFRS adopters as alternative treatment samples, and using voluntary IFRS adopters as an alternative benchmark sample. These analyses suggest that PEAD is reduced by the institution of IFRS, possibly together with strong enforcement or complementary shifts in enforcement in some countries, that overall increase financial reporting quality.
} 
In our study, we also investigate the channels through which the information shock affects PEAD. Consistent with our predictions, we find that the decrease in PEAD subsequent to the information shock is larger for firms with greater changes in financial reporting, an increase in analyst forecast accuracy and institutional ownership, and a reduction in limits to arbitrage. To further corroborate our inferences, we examine the effect of the information shock on the proportion of market reactions to earnings surprises after earnings announcements and the serial correlation of analysts' forecast errors. These analyses show that the proportion of total market reaction attributable to the drift decreases after the information shock and the decrease is more pronounced for non-Friday earnings announcements, when investor attention is high. We also find a decrease in the serial correlation of forecast errors. These findings are consistent with the notion that the information shock allows for faster reflection of earnings news in stock prices and the effects are stronger when investors are more attentive.

In addition to exploring the impact of mandatory IFRS adoption on PEAD, we expand our analyses to investigate alternative settings of improved financial reporting quality and other anomalies. Consistent with our expectation, we find that PEAD for non-U.S. firms decreases after a firm is cross-listed in the U.S. as well as after voluntary IFRS adoption. By comparison, we find no impact of the 1997 U.S. segment disclosure regulation, probably because disclosure quality in the U.S. was already relatively high prior to the regulation or segment disclosure involves a relative small change to financial reporting. We further find that the information shock reduces the earnings announcement premium but has no effect on return momentum or short-term reversal. This set of results is consistent with the idea that the information shock reduces earnings-related anomalies, but its effect on limits to arbitrage is insufficient to reduce other anomalies.

Our study contributes to the literature in several ways. First, we use a DID research design with a dramatic exogenous information shock. This new approach adds to the growing literature 
examining market anomalies such as value, momentum, accruals, asset growth, and idiosyncratic risks internationally. ${ }^{5}$ This literature investigates the reasons for anomalies outside the U.S. in order to improve our understanding of market efficiency and asset pricing worldwide. Griffin, Kelly, and Nardari (2010) suggest, however, that one cannot use anomaly measures such as PEAD to compare market efficiency across countries, because long-term, largely time-invariant firm and country factors have opposing influences on PEAD. To address this concern, we combine the information shock with a DID research design that controls for largely time-invariant firm and country factors. Consequently, our study is the first to lend support to the mispricing explanation for PEAD in an international setting.

Second, our setting allows us to expand our analyses to other events of increased financial quality in global markets. It also facilitates an examination of cross-country differences in the magnitude of PEAD and thus shed new light on the reasons for its existence. Our findings show that both limited investor attention and limits to arbitrage are important driving forces for PEAD. In addition, we find that investor distraction and arbitrage risks affect PEAD in developed markets while transaction costs influence PEAD in emerging markets. These findings are new and provide support to the arguments in Griffin Kelly, and Nardari (2010) that PEAD may result from information overload due to the limited attention of investors in developed markets but from high transaction costs of incorporating information in emerging markets.

Third, our paper extends the literature on U.S. markets that examines the effect of information environments on anomalies. In using a global sample, we differ from these U.S.-based studies in several ways. One difference is that we use the exogenous shock of mandatory IFRS adoption to

5 See, for example, Fama and French (1998), Rouwenhorst (1998), Griffin, Ji, and Martin (2003), Pincus, Rajgopal, and Venkatachalam (2007), Ang, Hodrick, Xing, and Zhang (2009), McLean, Pontiff, and Watanabe (2009), Watanabe, $\mathrm{Xu}, \mathrm{Yao}$, and Yu (2012), and Titman, Wei, and Xie (2013). 
capture changes in information quality. Another difference is that our selection reflects a shock that improves information quality throughout financial statements, and therefore is more comprehensive than the discretionary accruals used in prior research such as Francis, LaFond, Olsson, and Schipper (2007). In fact, we find that the effect of mandatory IFRS adoption on PEAD is not associated with changes in discretionary accruals, which suggests that a decline in discretionary accruals does not fully capture the improvement in financial reporting quality in our setting. A third difference is that prior research fails to find that common drivers of efficiency identified in the U.S. market, including information environments suggested in Zhang (2006), explain the level of PEAD outside the U.S. In comparison, we find improved information environments reduce PEAD in an international setting. We also complement Mendenhall (2004) and Vega (2006) by showing that PEAD decreases with proxies of information environments and informed traders subsequent to an information shock in an international setting. Overall, by examining PEAD in an international context, we provide out-of-sample tests for U.S.-based explanations.

Finally, we contribute to the literature on the impact of financial disclosure regulations on long-term market efficiency. Although financial disclosure is a critical component of capital market development and resource allocation efficiency (Diamond and Verrecchia 1991), a longstanding fundamental debate exists regarding the impact of regulations (Stigler 1964; Becker 1968). While earlier evidence on the impact of mandatory disclosure requirements is mixed (Healy and Palepu 2001), recent studies show positive economic consequences of disclosure requirements (Greenstone, Oyer, and Vissing-Jorgensen 2006). No prior work, however, has shown that disclosure regulation can improve market efficiency. Thus, our evidence complements this body of literature by showing that disclosure regulations can improve market efficiency, especially for those regulations related to financial reporting quality. 


\section{Institutional Setting and Empirical Predictions}

Our paper takes advantage of the 2005 mandatory IFRS adoption to study the impact of an information shock to corporate financial reporting. In 2005, thousands of companies worldwide ceased using domestic financial reporting standards and switched to IFRS, making IFRS the most widely used financial reporting standard in the world (Deloitte 2010). Compared to local financial reporting standards in many countries, IFRS is more investor-oriented and requires substantially more disclosure on items such as discontinued operations, segment reporting, cash flow statements, assets impairment, and share-based payments. This increase in disclosure requirements helps investors better identify cross-border similarities and differences between two sets of financial reports. Previous studies on the impact of IFRS have found that stock markets react positively to events associated with the mandatory IFRS adoption in Europe (Armstrong, Barth, Jagolinzer, and Riedl, 2010). Others find that mandatory IFRS adoption increases analyst forecast accuracy, foreign institutional ownership, and liquidity, and that the positive economic consequences are concentrated among firms with large, credible changes in financial reporting standards (Daske, Hail, Leuz, and Verdi 2008; Byard, Li, and Yu 2011; DeFond, Hu, Hung, and Li 2011; Tan, Wang, and Welker 2011).

Appendix A provides an example of financial reporting changes in earnings announcements subsequent to mandatory IFRS adoption. This example shows the changes for Finnair, from its 2004 financial results based on Finnish financial reporting standards to its 2006 results based on IFRS. From this example, we see that IFRS disclosures required more detail, as reflected in an increase of word count from 4,826 to 6,848 , as well as additional components in the income statement and balance sheet, a breakdown of the changes in working capital in the cash flow statement, a geographical segmental disclosure, and a statement of changes in shareholders' equity. 
Using the 2005 IFRS mandate as our information shock, our baseline analysis of the changes in PEAD is a test of the joint hypotheses that PEAD is driven by investors' incomplete reactions to earnings news and that the improved information quality associated with mandatory IFRS adoption reduces investor uncertainty. ${ }^{6}$ If both ideas are valid, we expect PEAD to decrease because the mispricing effects of mistaken beliefs should be weaker among firms about which there is lower uncertainty and richer information (Daniel, Hirshleifer, and Subrahmanyam 1998, 2001; Hirshleifer 2001; Kumar 2009). That is, better information quality about earnings news should increase the incorporation of earnings news into prices and reduce the return drift in the direction of earnings surprises.

There are several cross-sectional variations to this expectation based on prior findings in U.S.based studies. First, a lack of investor attention (due to numerous concurrent announcements from firms in other industries or relatively few sophisticated investors) or prohibitive limits to arbitrage (such as high transaction costs or arbitrage risks) may mitigate any potential impact of the information shock on PEAD. Thus, we expect the effect of mandatory financial reporting changes on PEAD to be greater among firms with fewer distractions, greater investor sophistication, lower transaction costs, and fewer arbitrage risks. Second, prior studies suggest that capital market development is associated with stronger law enforcement and less earnings management, both of which are critical in ensuring credible implementation of financial disclosure regulations (La Porta, Lopez-de-Silanes, Shleifer, and Vishny 1997; Leuz, Nanda, and Wysocki 2003). Thus, we predict the effect of mandatory financial reporting changes on PEAD will be greater in countries with more developed capital markets, stronger law enforcement, and less earnings management.

${ }^{6}$ If PEAD is driven by systematic risk, a decrease in PEAD subsequent to the information shock would require that financial disclosure affects systematic risk and that firms with unexpected high (low) earnings would become less (more) risky. This scenario is highly unlikely and difficult to reconcile with our cross-sectional evidence, such as the results on distraction effects and institutional holdings. 
Finally, prior research makes several predictions regarding the channels through which the financial reporting changes affect PEAD. For example, previous studies find that mandatory IFRS adoption, when associated with larger and more credible reporting changes, increases both analyst forecast accuracy (Byard, Li, and Yu 2011; Tan, Wang, and Welker 2011) and foreign institutional ownership (DeFond, Hu, Hung, and Li 2011), and reduces limits to arbitrage (Daske, Hail, Leuz, and Verdi 2008). Thus, we predict that a reduction in PEAD after IFRS adoption should be more pronounced for firms with a greater change in their financial reporting, an increase in analyst forecast accuracy, an increase in institutional ownership, or a decrease in transaction costs and arbitrage risks.

\section{Sample and Descriptive Statistics}

To determine our sample, we begin with a list obtained from Worldscope of all countries that required companies to switch to IFRS for fiscal years beginning on or after January 1, 2005. Our treatment sample includes mandatory IFRS adopters, companies that report under local financial reporting standards during the two years before the country mandates IFRS adoption (i.e., [-2, -1], the pre-shock period) and companies that report under IFRS during the two years after the mandate

(i.e., $[1,2]$, the post-shock period). To illustrate, a company with a December fiscal year-end would have a pre-shock period of 2003 and 2004 and a post-shock period of 2006 and 2007. Our benchmark sample consists of companies reporting under local financial reporting standards in non-IFRS adoption countries during the same sample period.

Next, we obtain earnings announcement dates, again from Worldscope for non-U.S. firms, and from I/B/E/S for U.S. firms (Acker and Duck 2009; Griffin, Hirschey, and Kelly 2011). Earnings surprises $(S U E)$ are calculated as $\mathrm{I} / \mathrm{B} / \mathrm{E} / \mathrm{S}$ actual earnings per share minus the last mean analyst consensus forecast before the earnings announcement dates, scaled by stock prices at least 6 but no 
more than 12 days prior to earnings announcements. We obtain our daily stock returns, market value-weighted index returns, daily stock prices, and daily trading volumes from CRSP for our U.S. firms and from Thomson Financial Datastream for the rest of our sample. To calculate the three-month, buy-and-hold abnormal returns following earnings announcements (POSTRET), we require a firm to have at least 44 non-zero daily returns during +2 to +64 trading days following the announcement. Firm characteristics, including firm size and market-to-book ratio, are based on accounting information obtained from Worldscope for non-U.S. firms and from Compustat for U.S. firms. Appendix B provides a detailed description of our variable definitions. To mitigate the influence of outliers (Griffin, Kelly, and Nardari 2010; Amihud, Hameed, Kang, and Zhang 2013), we winsorize all the continuous variables included in our regression analyses (i.e., POSTRET, SUE, SIZE, MTB, BETA, PRERET) at the top and bottom $1 \%$ of their distributions.

Finally, for firm-years with all the required variables for regression analyses, we require a firm to have at least one year's observation during the pre-shock period and at least one year's observation during the post-shock period. This requirement ensures that our findings are not driven by changes in sample composition around the information shock. For firms meeting this requirement, we further require a country-year to consist of at least 20 firms so that we can conduct a portfolio analysis in that country-year. These procedures yield a final sample of 1,921 firms (6,862 firm-years) from 18 treatment countries and 4,049 firms (14,258 firm-years) from 12 benchmark countries. Table 1 presents the sample distribution by country and time period. As shown in Table 1, the U.K. and the U.S. have the largest population of unique firms and total firmyears in treatment and benchmark countries, respectively, while the Philippines and Mexico have the smallest number of firms and observations in treatment and benchmark countries, respectively.

Table 2 presents the descriptive statistics for the variables used in our analyses. Panel A of this table reports the descriptive statistics for the firm characteristics in our main regression for our 
treatment and benchmark samples, respectively. This data shows that the mean POSTRET is $-0.92 \%$ for treatment firms and $-0.41 \%$ for benchmark firms. In addition, the mean earnings surprises $(S U E)$ are $0.17 \%$ for treatment firms and $2.31 \%$ for benchmark firms. Panel B reports the Pearson and Spearman correlations between the variables reported in Panel A for our treatment and benchmark samples, respectively. From Panel B, we see that POSTRET is positively correlated with SUE for both samples, with Pearson correlation coefficients of 0.0219 and 0.0837 and Spearman correlation coefficients of 0.0518 and 0.0819 for treatment sample and benchmark sample, respectively. The correlations between our other variables display generally comparable patterns between our treatment and benchmark samples.

\section{Empirical Results}

\subsection{Univariate and country portfolio analyses}

Table 3 presents the results of our univariate analysis of PEAD in the pre- and post-shock periods by country. In every country-year, we partition the sample into five quintiles based on earnings surprises, with the top and bottom quintiles comprising observations with the most positive and negative earnings surprises, respectively. In every country-period, we calculate $P E A D$ as the difference in the mean POSTRET between firm-years in the top quintile and firm-years in the bottom quintile. The average PEAD of the treatment (benchmark) countries in each period is calculated as the difference in the mean POSTRET between all firm-years of treatment (benchmark) countries in the top quintile and all firm-years of treatment (benchmark) countries in the bottom quintile. Columns (1) and (2) present the results for PEAD in the pre-shock and post-shock periods, respectively. Column (3) reports the change in PEAD between the two periods for each country.

The results in Column (1) show that PEAD is present in ten out of the 18 treatment countries and eight out of the 12 benchmark countries during the pre-shock period, with an average PEAD of 
$2.44 \%$ and $2.80 \%$ in treatment and benchmark countries, respectively. On average, PEAD does not differ significantly between the treatment and benchmark countries during the pre-shock period. The results in Column (2) show that $P E A D$ is marginally significant in six treatment countries and seven benchmark countries during the post-shock period. On average, PEAD in treatment countries becomes insignificant after the shock, but remains significantly positive in the benchmark countries. Further, we see that the average $P E A D$ of the treatment countries becomes significantly lower than that of benchmark countries. The results in Column (3) show that PEAD decreases significantly from the pre- to post-shock period in ten treatment countries, with an average decrease of $1.38 \%$ compared to an average increase of $1.35 \%$ for the benchmark countries. Overall, the findings suggest that the treatment sample experiences a greater reduction in PEAD than the benchmark sample.

Examining the results in Table 3 further, Panel B of Table 3 reports the results of a countrylevel regression analysis where the dependent variable is the PEAD of every country-year. Specifically, the country-year PEAD is calculated as the difference in the mean POSTRET between firms in the top quintile and firms in the bottom quintile of each country-year. Consistent with the results in Panel A of Table 3, the intercept, which represents the PEAD of the benchmark countries during the pre-shock period, is significantly positive. The coefficient on Treatment is insignificant, suggesting that there is no difference in $P E A D$ between the treatment and benchmark countries during the pre-shock period. The coefficient on POST is also insignificant, indicating no changes in $P E A D$ in the benchmark countries after the information shock. Most importantly, the coefficient on POST $\times$ Treatment is significantly negative, suggesting that treatment countries experience a significant reduction in $P E A D$ relative to the benchmark countries.

To investigate whether PEAD is sufficiently stable over time to allow for meaningful conclusions from our results, we compute the annual average of PEADs from 2001 to 2009 for our 
treatment and benchmark samples. ${ }^{7}$ The results, plotted in Figure 1, show the existence of PEAD for both samples for every year except 2008 (the peak of the global financial crisis). We conjecture that the small negative PEAD in 2008 is because investors may perceive earnings news differently and government interventions may have distorted the market to some extent during the crisis period. This finding is consistent with a recent study by Daniel and Moskowitz (2013), who find that return momentum reverses during the global financial crisis and exhibits negative quintile spread returns. The figure further shows that in general, treatment and benchmark countries display similar trend over time. We note, however, the univariate analysis in Table 3 and Figure 1 do not control for firm characteristics that may influence PEAD. Thus, we rely on our multivariate analysis in the next section to assess the impact of the information shock on PEAD.

\subsection{Multivariate analysis}

In this section, we first model the temporal changes in PEAD within our treatment and benchmark samples. We then compare changes in PEAD in our treatment countries to changes in PEAD in our benchmark countries subsequent to the information shock. Specifically, we estimate the following two equations:

$$
\begin{aligned}
\text { POSTRET }= & \beta_{0}+\beta_{1} Q S U E+\beta_{2} P O S T \times Q S U E+ \\
& \Sigma \beta_{k}(\text { Firm characteristics, country/industry/year fixed effect })+\varepsilon \\
\text { POSTRET }= & \beta_{0}+\beta_{1} Q S U E+\beta_{2} P O S T \times Q S U E+\beta_{3} P O S T \times \text { Treatment }+ \\
& \beta_{4} Q S U E \times \text { Treatment }+\beta_{5} P O S T \times Q S U E \times \text { Treatment }+ \\
& \Sigma \beta_{k}(\text { Firm characteristics, country/industry/year fixed effect })+\varepsilon,
\end{aligned}
$$

where POST is a dummy variable that takes the value of one for the post-shock period, and zero otherwise. Treatment is an indicator variable that takes the value of one if a firm is from a country that mandates IFRS starting with the fiscal year ending on December 31, 2005, and zero otherwise.

\footnotetext{
${ }^{7}$ We end the period in 2009 because three benchmark countries, Brazil, Canada, and South Korea, adopt IFRS in 2010, 2011, and 2011, respectively. Since requiring a firm to exist over a long period will lead to a severe survivorship bias, Figure 1 requires a firm to be present in only one of the three windows used in the tests of Table 4: main analysis, prepseudo adoption test, and post-pseudo adoption test.
} 
$Q S U E$ is the scaled quintile rank of earnings surprises (SUE), ranging from zero to one, in every country-year. Note that since $Q S U E$ ranges from zero to one, its coefficient, $\beta_{1}$, represents the magnitude of $P E A D$ when moving from the bottom quintile to the top quintile. Firm characteristics in the above equation include firm size (SIZE), measured as the logarithm of the market value of equity in millions of U.S. dollars at the end of the fiscal year; market-to-book (MTB), measured as the ratio of the market value of equity to the book value of equity at the end of the fiscal year; market model beta (BETA), estimated from regressing daily stock returns on daily value-weighted market index returns during the one-year period before the earnings announcement; and return momentum (PRERET), measured as the three-month buy-and-hold returns (skipping the most recent month) before earnings announcements, adjusted for contemporaneous buy-and-hold, valueweighted market index returns. Our regressions also include country-, industry-, and year-fixed effects, with the standard errors of the coefficient estimates adjusted by country cluster (Petersen 2009). ${ }^{8}$

In equation (1), the interaction term, $\beta_{2}$, captures the change in PEAD for the treatment sample after 2005; in equation (2), the interaction term, $\beta_{5}$, captures the incremental change in PEAD for treatment group after 2005 relative to the change for the benchmark group. If the information shock leads to a decline in PEAD, we expect a negative coefficient on both $\beta_{2}$ and $\beta_{5}$.

Our coefficient estimates of equation (1) for our treatment countries are presented in Columns (1) and (2) of Table 4. Column (1) shows a significantly negative coefficient on $P O S T \times Q S U E$. Column (2) yields similar results after controlling for firm characteristics, indicating that treatment countries experience a post-shock decrease in PEAD. This result is economically significant, with a $2.75 \%$ decrease in the quarterly abnormal returns generated by PEAD after the information shock.

\footnotetext{
${ }^{8}$ We do not include the dummy variables indicating POST and Treatment, because the effects of these variables are subsumed by the year fixed effects and country fixed effects, respectively.
} 
Coefficient estimates of equation (1) for our benchmark countries are presented in Columns (3) and (4). Column (3) shows a marginally significant coefficient on $P O S T \times Q S U E$. This coefficient in Column (4) becomes insignificant after controlling for firm characteristics, indicating no material changes in PEAD in benchmark countries.

Equation (2) estimates, including both treatment and benchmark firms and a DID design, are presented in Columns (5) and (6) in Panel A of Table 4. Here, we see that the coefficients on QSUE are significantly positive, while the coefficient on $P O S T \times Q S U E$ is insignificantly different from zero when we control for firm characteristics, suggesting that the benchmark group does not experience a change in PEAD subsequent to the information shock. In addition, both columns show that the coefficients on QSUE×Treatment are insignificantly different from zero, suggesting that there is no difference in PEAD between the treatment and benchmark groups before the information shock. Most importantly, the coefficients on POST $\times Q S U E \times$ Treatment are significantly negative in both columns, indicating that, relative to the benchmark firms, the treatment firms experience a significant decline in PEAD after the information shock. With regard to control variables, the negative coefficients on BETA are consistent with those obtained by Frazzini and Pedersen (2014).

\subsection{Robustness checks of the main results}

3.3.1 Concurrent events. To mitigate potential concerns that the findings in Panel A of Table 4 are driven by concurrent institutional or economic changes unrelated to the information shock, we conduct various robustness checks and present the results in this section. For brevity, we omit the reporting of the coefficients on our control variables. First, we address the concern that five EU countries with concurrent enforcement changes (i.e., Finland, Germany, the Netherlands, Norway, and the U.K) are driving our overall results. Christensen, Hail, and Leuz (2013) find that this set of five EU countries proactively began to review financial statements concurrent with the IFRS 
reporting mandate, and conclude that overall non-U.S. improvements in liquidity after the mandate are due to these five countries. To address this concern, we repeat our analysis after restricting the treatment sample to (1) European countries, (2) non-European countries, (3) the five countries with concurrent enforcement changes, and (4) the other countries without concurrent enforcement changes. The findings in Columns (1)-(4) of Panel B, Table 4 show similar results using these different country subsets, suggesting the impact of the information shock on PEAD extends beyond the EU countries with concurrent enforcement changes. These analyses suggest that the institution of IFRS, possibly together with strong enforcement or complementary shifts in enforcement in some countries, increases financial reporting quality that in turn decreases PEAD.

Second, we run our analyses using a sample of countries mandating IFRS in years other than 2005: Singapore (2003), Turkey (2006), New Zealand (2007), Pakistan (2007), Israel (2008), Brazil (2010), Canada (2011), and South Korea (2011). We find similar results, reported in Column (5) of Table 4, Panel B, suggesting that our inferences are generalizable to non-2005 IFRS adoption settings. ${ }^{9}$

Finally, we repeat our analysis after benchmarking our treatment sample against voluntary IFRS adopting firms coming from the same country and excluding treatment countries that do not have any voluntary IFRS adopters (as reported in Table 5). This benchmark helps alleviate the concern of concurrent events, because concurrent events should affect both voluntary and mandatory adopters in a similar way due to their economic and regulatory commonalities. In addition, since voluntary adopters adopt IFRS prior to the information shock, their financial reporting practices remain unchanged during the information shock period. Column (6) of Panel B,

${ }^{9}$ For this test, we include only treatment firms because using non-2005 mandatory adopters makes it difficult to code the post-shock years for the benchmark sample in the DID test. In addition, due to the lack of I/B/E/S coverage for the small economies and a very short post-shock period for countries such as Brazil and Canada, we impose our data constraint based on Worldscope and use a time-series earnings expectation model. Since 2008 is the peak of financial crisis and shows a worldwide drop of PEAD, we replace 2008 in the post-shock period with 2009 and 2010 for the 2006 and 2007 adopters, respectively, and replace 2008 in the pre-shock period with 2007 for the 2010 adopter. 
Table 4 show that the coefficient on $P O S T \times Q S U E \times T$ Treatment remains significantly negative, suggesting that our result is not sensitive to the alternative benchmark of voluntary adopters.

3.3.2 Identification issues with the DID approach. Our DID design requires a zero correlation assumption, namely that, in the absence of treatment, the average change in the response variable would have been the same for both the treatment and control groups. Thus, in addition to using voluntary adopters as an alternative benchmark, we perform several additional robustness checks to mitigate the concern that our treatment and benchmark samples may not be comparable because they are divided by countries.

We begin by conducting two pseudo-adoption tests. The first pseudo-adoption test uses the period prior to the information shock (2001-2004), with 2001-2002 as the pseudo pre-shock period and 2003-2004 as the pseudo post-shock period. The second pseudo-adoption test uses the period subsequent to the information shock (2006-2009), with 2006-2007 as the pseudo pre-shock period and 2008-2009 as the pseudo post-shock period. The results, presented in Columns (1) and (2) of Table 4, Panel C, show that the coefficient on POST $\times Q S U E \times$ Treatment becomes insignificant at conventional levels in both tests. These findings suggest that, in the absence of treatment, our treatment and benchmark samples exhibit a similar trend in PEAD.

Next, we repeat our analysis after restricting the sample to firms in either developed or emerging markets (Griffin, Kelly, and Nardari 2010). Firms in countries within either group should be more comparable. Again, the results in Columns (3) and (4) of Table 4, Panel C yield similar results. ${ }^{10}$

${ }^{10}$ We find our results remain qualitatively the same in several additional robustness tests regarding the DID identification issue, including: (1) excluding the U.S. from our benchmark, (2) using either firm-level or country-level propensity score matching methods to pair up treatment sample and benchmark sample, (3) dropping financial firms, and (4) relaxing the requirement that a firm needs to present in both the pre- and post- shock periods. 
3.3.3 Alternative specifications. We next examine whether our findings are sensitive to alternative specifications of earnings surprises (SUE). To do so, we repeat our analysis after using (1) the decile rank of earnings surprise in each country-year, scaling the rank between zero and one; (2) the same cut-off of earnings surprises to all the country-years, thus forming portfolios; and (3) a naïve time-series earnings expectation model that uses the prior year's reported earnings as an expectation of current year earnings. The analyses (untabulated) continue to find qualitatively similar results when we use alternative specifications of earnings surprises. We do not use twoway country- and year- clusters in our main tests because our main tests cover only four years of data and this approach would lead to missing t-statistics. Nonetheless, our results remain when we adjust standard errors for country- and year-clusters as well as when we do so after demeaning the dependent and control variables for each year. Overall, these analyses provide further confidence that the observed post-shock decrease in PEAD reflects an improvement in reporting quality and subsequent reduction of mispricing.

\section{Analysis of Alternative Events of Increased Financial Reporting Quality}

To further ensure the validity of our inferences, in this section, we consider other scenarios that result in improved financial reporting quality. These scenarios include cross-listing on a U.S. exchange (Baily, Karolyi, and Salva 2006), voluntary IFRS adoption (Covrig, DeFond, and Hung 2007), and segment disclosure following the 1997 U.S. mandate of SFAS131. Because the first two events are spread out over time and are generally not clustered across time or geographic regimes, they are less likely to be affected by concurrent events, which should help further alleviate the concern that concurrent events are driving our results.

We obtain our cross-listing data from various sources, including Bank of New York, Citibank, JP Morgan, and the NYSE and NASDAQ websites, focusing on the 1994-2012 period. We 
identify our voluntary adopters as non-U.S. firms adopting IFRS prior to 2005 . We identify our segment disclosure sample as U.S. firms reporting more operating segments subsequent to 1997. After imposing the same data requirement as our main analysis, we obtain 788 unique cross-listing firms, 606 unique voluntary adoption firms, and 625 U.S. firms reporting increased operating segments. Panel A of Table 5 reports the sample distribution for each event. ${ }^{11}$

Panel B of Table 5 presents the results of the regression analyses. First, we find that the coefficient on $P O S T \times Q S U E$ is significantly negative in Column (1), suggesting that cross-listed firms experience a reduction in PEAD subsequent to being cross-listed on a U.S. exchange. This change is also economically significant, as cross-listing reduces quarterly abnormal returns by $3.99 \%$ (i.e., the coefficients on $P O S T \times Q S U E$ ). Second, we find that the coefficient on $P O S T \times Q S U E$ is significantly negative in Column (2), suggesting that voluntary adopters also experience a reduction in PEAD subsequent to the adoption. Economically, this yields a decrease of $0.74 \%$ in quarterly abnormal returns. Finally, for our segment disclosure sample, we find that the coefficient on POST $\times Q S U E$ in Column (3) and the coefficient on POST $\times Q S U E \times T$ Treatment in Column (4) are both negative but insignificant. This finding may reflect the fact that U.S. reporting quality is already high or that segment disclosure involves a relative small change to financial reporting.

Overall, we find that PEAD decreases subsequent to cross-listing on U.S. stock exchanges and voluntary IFRS adoption, but does not change subsequent to the 1997 U.S. segment disclosure regulation. Combined with our results from mandatory IFRS adoption, this set of results suggests

\footnotetext{
${ }^{11}$ We exclude foreign firms that adopt IFRS and cross-list in the U.S. after 2007, the year when the SEC begins accepting financial statements prepared according to IFRS from foreign private issuers. The wide variation in the number of voluntary IFRS adopters across countries is partially due to that some countries, such as the U.K. and the U.S., require firms to use local financial reporting standards in their public financial reports. For both cross-listing and the voluntary IFRS adoption analysis, we adjust robust standard errors using two-way country- and year- clusters, because the events occur over many years.
} 
that the effect of increased financial reporting quality on PEAD depends on the extent of financial reporting changes.

\section{Analyses Conditional on Firm- and Country-level Determinants}

This section presents the results of our tests related to two sources of PEAD put forth by prior research: limited investor attention and limits to arbitrage. In addition, we examine how countrylevel institutions affect changes in PEAD subsequent to the information shock as well as how they interact with the underlying sources of PEAD.

\subsection{Limited investor attention}

Hirshleifer, Lim, and Teoh (2009) argue that concurrent earnings announcements by other firms can distract investors from the task of valuing a given firm. Such distractions can weaken the market's reaction to a given firm's earnings surprise and therefore exacerbate PEAD. Furthermore, they find that unrelated news (i.e., concurrent earnings announcements made by firms from other industries) is more distracting than related news. Since distracted investors are less likely to base their investment decisions on analyses of financial statements, we expect to find a greater reduction in PEAD for our sample firms with less distracting environments.

To measure the level of distraction, we use the number of concurrent earnings announcements issued by firms from other industries but in the same region as a given firm. We restrict this analysis to the same region to reflect analyst benchmark protocol (Bae, Stulz, and Tan 2008). ${ }^{12}$ Our industry classification follows the Fama-French 30-industry definitions and our region classification follows the United Nations' Geoscheme. Specifically, for every firm-year, we first count the number of earnings announcements issued on the same day by firms from other

\footnotetext{
${ }^{12}$ Our result remains qualitatively the same if we consider the number of concurrent earnings announcements issued by firms from other industries worldwide.
} 
industries but in the same region. Next, in every year, we partition the full sample into two groups based on the sample median value of the number of concurrent earnings announcements in that year.

In addition to gauging investor distraction, we consider the impact of the information shock on PEAD based on the level of investor sophistication. Consistent with the notion that institutional investors are more sophisticated than individual investors, Ke and Ramalingegowda (2005) find that institutional investor trading around earnings announcements attenuates PEAD. Since institutional investors should also have a greater attention span as well as greater learning capacity, they should be better equipped to take advantage of financial reporting quality improvements. Thus, we expect PEAD to decrease more in treatment firms with greater institutional ownership.

We obtain our institutional ownership data from LionShare. For firm-years with available ownership data, we partition the sample firms into two groups based on the median value of the institutional ownership percentage in every country-year.

Panel A of Table 6 presents the results of our multivariate analysis for changes in PEAD, conditional on distraction effects and investor sophistication. Columns (1)-(2) present the results for changes in PEAD conditional on the number of concurrent earnings announcements. Columns (3)-(4) present the results for changes in PEAD conditional on institutional ownership. The Chisquare statistics reported at the bottom of the panel show that PEAD weakens more in firms that suffer from fewer concurrent earnings announcements as well as firms with a greater proportion of institutional holdings, significant at the $5 \%$ level (one-tailed). ${ }^{13}$ These findings are consistent with our predictions and suggest that an important source of PEAD is limited investor attention.

\footnotetext{
${ }^{13}$ We report the significance of coefficients using two-tailed $p$-values. However, we report the significance of the difference across partitions using one-tailed $p$-values because we expect the decline in PEAD subsequent to the information shock to be stronger for firms with fewer distraction effects, more sophisticated investors, lower transaction costs, and fewer arbitrage risks, as well as among firms from countries with more developed capital markets and stronger enforcement.
} 


\subsection{Limits to arbitrage}

In an ideal setting where arbitrage opportunities are riskless, obvious, and costless to exploit, the impact of an information shock on PEAD should be immediate. In reality, however, where arbitrage is risky and costly, PEAD could be more persistent. Thus, we expect the effect of the information shock on PEAD to be more pronounced for firms with lower limits to arbitrage.

Following prior studies (Mendenhall 2004; Lam and Wei 2011), we examine two ways in which arbitrage can be limited, namely transaction costs and arbitrage risks. To measure transaction costs, we use the Amihud (2002) measure of illiquidity (AMIHUD), defined as the mean value of the absolute daily returns divided by the daily dollar trading volume (in millions of US dollars) between -252 to -2 trading days before the earnings announcement. To measure arbitrage risks, we use idiosyncratic volatility $(I V O L)$. This volatility captures the component of a stock's risk that cannot be hedged and is measured as the standard deviation of residual values from the time-series market model: $R_{i t}=b_{0}+b_{1} R_{M t}+e_{i t}$, where $R_{i t}$ is the daily stock return and $R_{M t}$ is the daily value-weighted market index return, estimated between -252 to -2 trading days before the earnings announcement. For every country-year, we partition the sample firms into two groups based on the median value of these two measures.

Our results for the impact of our information shock on PEAD, conditional on limits to arbitrage are reported in Panel B of Table 6. Here, low Amihud illiquidity indicates low transaction costs while low idiosyncratic volatility indicates low arbitrage risks. The results show that firms with lower Amihud illiquidity and lower idiosyncratic volatility experience a greater decline in PEAD subsequent to the information shock.

\subsection{Potential dominance of limited investor attention or limits to arbitrage}

Given that limited investor attention and limits to arbitrage each play a role in the extent to which PEAD is impacted by the information shock, an interesting question is whether one 
dominates the other in its influence. On theoretical grounds we expect the two to interact. The combination of both limits to arbitrage and investor misperceptions is needed for mispricing (if there are also smart investors who are not subject to misperceptions). Our research design, with global cross-sectional variations, allows us to examine this issue. We first sort our firms based on investor attention vs. limits to arbitrage. We then examine the sum of the coefficients on $P O S T \times Q S U E$ and $P O S T \times Q S U E \times T$ Treatment (i.e., changes in PEAD in the treatment sample after the information shock) across these two subsamples split by our two measures of investor attention and two measures of limits to arbitrage.

The results of this analysis, reported in Panel C of Table 6, reveal several notable findings. First, we find that concurrent earnings announcements and institutional ownership are important in reducing PEAD after the information shock only when Amihud illiquidity is low. Furthermore, we find that Amihud illiquidity reduces PEAD more so when there are few concurrent earnings announcements. Together, these results suggest a complementary role between investor attention and transaction costs.

We further find that concurrent earnings announcements and institutional ownership are important in reducing PEAD after the information shock when idiosyncratic volatility is high. In addition, we find that low idiosyncratic volatility reduces PEAD when there are more concurrent earnings announcements or when there is less institutional ownership. These results suggest that investor attention and arbitrage risks are likely substitutes for each other.

Finally, we find the greatest reduction in PEAD at the intersection when distraction effects are low, or investor sophistication is high, as well as when the transaction costs are small, or arbitrage risks are low. By contrast, we find the smallest reduction in PEAD when distraction effects are high, or investor sophistication is low, as well as when the transaction costs are large, or arbitrage risks are high. Overall, consistent with our expectation, these findings suggest that the decrease in 
PEAD after the information shock is more likely to be a joint effect of investor attention and limits to arbitrage. Thus we conclude that neither factor dominates in its influence.

\subsection{Country-level institutions}

Another interesting consideration in our analysis is whether the observed effect of the information shock on PEAD varies across countries. In particular, we expect that countries with capital markets subject to stronger law enforcement and fewer opportunities for earnings management will exhibit a stronger impact of the information shock on PEAD.

To study this question, we measure Capital market development as the mean rank across three variables used in La Porta, Lopez-de-Silanes, Shleifer, and Vishny (1997): (1) the ratio of the aggregate stock market capitalization held by minorities to gross national product, (2) the number of listed domestic firms relative to the population, and (3) the number of IPOs relative to the population. Each variable is ranked such that a higher score indicates greater market development. We measure a country's law enforcement using Rule of law, the rule of law index constructed by Kaufmann, Kraay, and Mastruzzi (2007). We measure reporting credibility using Earnings management, the aggregate earnings management score from Leuz, Nanda, and Wysocki (2003). We then partition our sample countries into two groups based on the country-level median value of these measures and compare changes in PEAD across the subgroups.

The results of this analysis, reported in Panel A of Table 7, show that firms in countries with more developed capital markets, stronger rule of law, or lower earnings management experience a greater decrease in PEAD after the information shock. These findings lend further support to our

prediction and suggest that the effect of the information shock on PEAD depends on both a country's capital market development and its enforcement credibility.

\subsection{The role of country-level institutions on limited investor attention and limits to arbitrage}


Griffin, Kelly, and Nardari (2010) find that the magnitude of PEAD is not correlated with measures of capital market development. They further propose that the impact arises from information overload in developed markets but high transaction costs in emerging markets. To consider this possibility, we separate our firms into high and low capital market development subgroups and further sort each subgroup into two subsamples based on each of our measures of investor attention and limits to arbitrage. We then examine the sum of the coefficient on $P O S T \times Q S U E$ and $P O S T \times Q S U E \times$ Treatment (i.e., net changes in PEAD in the treatment sample after the information shock) across the subsamples.

Our results, presented in Panel B of Table 7, show that fewer distraction effects and lower arbitrage risks have a greater impact for firms in more developed capital markets. By contrast, we find that low transaction costs play a greater role for firms in emerging markets. These findings complement those of Griffin, Kelly, and Nardari (2010) and suggest different effects of limited attention and limits to arbitrage on PEAD across different markets.

\section{Additional Analyses}

\subsection{The channels through which the information shock affects PEAD}

This section provides the results of our analysis of the channels through which the information shock reduces PEAD. As discussed, we expect the observed reduction in PEAD to be greater for firms with greater changes in financial reporting, an increase in analyst forecast accuracy and institutional ownership, or a reduction in transaction costs and arbitrage risks. ${ }^{14}$

To measure the extent of financial reporting changes, we use the extent to which a firm restates key financial statement items after transitioning from local GAAP to IFRS. Firms

\footnotetext{
${ }^{14}$ While PEAD can also decrease due to a reduction in concurrent earnings announcements, we do not expect this to be a channel through which the information shock decreases PEAD, because the information shock also encourages more timely reporting (Landsman, Maydew, and Thornock 2012).
} 
adopting IFRS for the first time are required to restate prior year's financial statements. The extent of restatement is an outcome-based measure of financial reporting changes that reflects both managers' reporting incentives and accounting differences between local GAAPs and IFRS. ${ }^{15}$ Specifically, using restatement data from Worldscope, we identify the ten most frequently restated financial statement items, including seven balance sheet items (short-term investment, PPE, intangible assets, leases, deferred taxes, provisions, and post-retirement benefits), and three income statement items (revenue, cost of goods sold, and discontinued operations).

We next create two alternative measures to capture the extent of the financial reporting changes caused by IFRS adoption. The first measure, $\triangle G A A P 1$, is a dummy variable indicating whether the financial reporting change of a treatment firm is above the $25^{\text {th }}$ percentile of all treatment firms. The second measure, $\triangle G A A P 2$, is a dummy variable indicating whether a treatment firm is from a country-industry with a mean financial reporting change above the $25^{\text {th }}$ percentile of all country-industries of the treatment sample. We use a dichotomous dummy variable to capture financial reporting changes because if the underlying variable has a threshold, beyond which the effect is more or less effective, then dichotomizing may better capture the effect. For both $\triangle G A A P 1$ and $\triangle G A A P 2$, we compile two sub-indices based on changes in balance sheet items $\left(\triangle G A A P 1_{B / S}\right.$ and $\left.\triangle G A A P 2_{B / S}\right)$, and income statement items $\left(\triangle G A A P 1_{I / S}\right.$ and $\left.\triangle G A A P 2_{I / S}\right)$, respectively.

To measure changes in analyst forecast accuracy, we use data from I/B/E/S on the most recent earnings forecasts issued by every analyst within 180 trading days before the earnings announcement for every firm-year. We then use this data to calculate an analyst mean consensus

${ }^{15}$ As an example of the permanent effect of financial reporting changes on key financial statements, IFRS requires some operating leases under local GAAP be treated as financing leases. This requires the recognition of previously offbalance sheet liabilities and assets, which in turn affects income statements through depreciation and interest expenses. 
forecast for the corresponding firm-year. The earnings forecast error for every firm-year is calculated as the absolute value of the difference between actual earnings and the analyst mean consensus forecast, scaled by stock prices at the end of the fiscal year. Thus, an increase in forecast accuracy is defined as a decrease in the earnings forecast error from the pre-shock to the postshock period.

Finally, we calculate changes in institutional holdings as differences in the mean value of annual institutional holdings between the pre-shock and post-shock periods. We calculate changes in transaction costs as changes in the mean values of annual Amihud illiquidity and changes in arbitrage risks as changes in the mean values of annual idiosyncratic volatility from the pre-shock period to the post-shock period.

In conducting our analysis of channels, we restrict our sample to only treatment firms because benchmark firms do not change accounting standards during our sample period. In addition, we define a dummy variable, FACTOR, to indicate treatment firms experiencing a greater financial reporting change, an increase in analyst forecast accuracy and institutional ownership, or a reduction in limits to arbitrage during the post-shock period.

We present the results of this analysis in Table 8. Specifically, the results in Panel A show a significantly negative coefficient on $P O S T \times Q S U E \times F A C T O R$ in all columns, suggesting that PEAD declines more among treatment firms experiencing a greater financial reporting change after the information shock. ${ }^{16}$ The results in Panel B show significantly negative coefficients on $P O S T \times Q S U E \times F A C T O R$ in all columns, suggesting that the reduction in PEAD is also more pronounced among treatment firms with an increase in analyst forecast accuracy and institutional

\footnotetext{
${ }^{16} \mathrm{We}$ also perform an analysis based on each of the ten individual balance sheet and income statement accounts. At the firm level, we find that eight of the ten coefficients on the interaction term POST $\times Q S U E \times F A C T O R$ have the expected negative sign, although only three are significant. At the country-industry level, we find that all the coefficients on $P O S T \times Q S U E \times F A C T O R$ are negative, with six significantly so. The weaker result for the individual components is consistent with the notion that the summary score captures the collective effect of financial reporting changes.
} 
holdings, or a reduction in limits to arbitrage. Overall, these findings lend further support to our prediction that improved financial reporting quality mitigates PEAD, and that it does so via enhanced disclosures, greater earnings forecast accuracy, higher institutional interests, and lower limits to arbitrage. ${ }^{17,18}$

\subsection{The effect of the information shock on the market reaction to earnings announcements attributable to the drift}

One alternative explanation for our main finding is that PEAD may decrease after the information shock because the shock improves the information environment and thus reduces the informativeness of earnings announcements. To address this alternative explanation, we examine the proportion of the total stock market reaction to earnings announcements attributable to the drift. We calculate the proportionate drift as the market reaction to earnings surprises during the postearnings-announcement period (i.e., during the event window $[+2,+64]$ trading days), scaled by the market reaction to earnings surprises during both the earnings announcement period and the post-announcement period (i.e., during the event window $[-1,64]$ trading days). In this case, higher abnormal return volatility and trading volume during the earnings announcement period as documented by Landsman, Maydew, and Thornock (2012), accompanied by a lower total stock market reaction during the post-earnings-announcement period, would support our conclusion that increased financial reporting quality helps speed up the incorporation of earnings news into stock prices upon earnings announcements.

\footnotetext{
${ }^{17}$ In additional analyses (untabulated), we find that the reduction in PEAD does not differ between treatment firms experiencing a decrease in absolute value of discretionary accruals and other treatment firms. This finding suggests that the information shock improves financial reporting quality through increased disclosure and improved comparability, rather than through a firm's earnings properties (Ahmed, Neel, and Wang 2013).

${ }^{18} \mathrm{We}$ also find greater reductions in PEAD for firms experiencing a reduction in alternative liquidity measures suggested by Daske, Hail, Leuz, and Verdi (2008), including the number of zero-return days, the bid-ask spread, and LDV trading costs.
} 
We also perform analyses conditional on Friday versus non-Friday earnings announcements. DellaVigna and Pollet (2009) document less immediate market response and more drift for earning announcements on Friday, when investor inattention is more likely. Thus, if increased financial reporting quality facilitates an immediate response to earnings and reduces the drift in the postannouncement period, we expect the effect to be stronger for non-Friday earnings announcements, when investors are more attentive.

To test the change in the proportionate drift, we re-estimate equations (1) and (2) using stock returns during two separate windows: (1) the earnings announcement window [-1 to +1 trading days around the earnings announcement] and (2) the post-earnings-announcement window [+2 to +64 trading days after the earnings announcement]. We calculate the proportionate drift as the coefficient on earnings surprises during the post-announcement window scaled by the sum of the coefficients on earnings surprises during the announcement window and the post-announcement window. We can then test the difference in proportionate drift between the pre- and post-shock periods.

Table 9 reports the results of these tests. Panel A reports the results for the average effect, and Panel B reports the results conditional on Friday and non-Friday earnings announcements. The results in Columns (1) and (2) of Panel A show that, in treatment countries, the proportion of market reactions after earnings announcements decreases from $58.99 \%$ during the pre-shock period to $3.43 \%$ during the post-shock period. The results in Columns (3) and (4) exhibit the same pattern for the full sample, with the proportionate drift decreasing from $60.77 \%$ during the preshock period to $4.35 \%$ during the post-shock period for the treatment firms. In sharp contrast, the proportionate drift remains stable from the pre-shock to post-shock period for the benchmark firms. Panel B shows that among treatment firms, the proportionate drift decreases from $58.89 \%$ during the pre-shock period to $2.30 \%$ during the post-shock period for non-Friday earnings 
announcements. In contrast, the proportionate drift does not statistically change for Friday earnings announcements. For benchmark firms, the proportionate drift remains stable from the pre-shock to the post-shock period regardless of when firms announce their earnings.

Overall, the findings in Table 9 corroborate our conclusion that the information shock speeds up the incorporation of earnings announcement information into stock prices, and the effects are stronger when investors are more attentive.

\subsection{The effect of the information shock on the serial correlation in analyst forecast errors}

To provide further support for our finding that the reduction in uncertainty created by improved financial reporting leads to a decrease in PEAD, we examine the serial correlation in analyst forecast errors after the information shock. To the extent that PEAD is a result of investor incomplete reactions to current earnings news, financial reporting quality improvement should accelerate analyst responses to future implications of currently announced earnings and therefore reduce the serial correlation in their forecast errors.

We follow the procedure outlined in Kimbrough (2005) for our tests in this section. To test the serial correlation in analyst forecast errors, we collect $\mathrm{I} / \mathrm{B} / \mathrm{E} / \mathrm{S}$ data on an analyst's most recent forecast of year $t$ 's earnings issued within 180 trading days before the earnings announcement and the same analyst's earliest forecast of year $t+1$ 's earnings issued within 64 trading days (i.e., the three-month period in which we measure the PEAD) upon year $t$ 's earnings announcement. For each firm-year, we calculate the mean values of forecast errors for years $t+1$ and $t$; we then test the serial correlation in the mean values of the forecast errors over the two-year period.

Table 10 reports the results of this analysis. The results in Columns (1) and (2) indicate a significant and positive coefficient on $F E_{\mathrm{t}}$, suggesting a positive pre-shock serial correlation in forecast errors in both treatment and benchmark samples. Furthermore, the coefficient on $F E_{t} \times P O S T$ is insignificant in Column (1) while the coefficient on $F E_{t} \times P O S T \times T r e a t m e n t$ is 
significantly negative in Column (2). These results suggest that there might be an overall increase in the serial correlation in the forecast errors in both treatment and benchmark samples and that this increase is independent of the information shock. Controlling for this increase in the benchmark sample, we find that the treatment group experiences a reduction in serial correlation of forecast errors relative to the change in the benchmark sample. These findings corroborate our argument that the reduced uncertainty associated with the information shock decreases investor incomplete reactions to earnings news.

\subsection{The impact of the information shock on other anomalies}

While the primary focus of our paper is the effect of the information shock on PEAD, an interesting extension of our study is whether this information shock affects other measures of market efficiency. We provide insight into this issue by extending our analysis to another earnings-

related anomaly, the earnings announcement premium, and two return-related trading-based anomalies, momentum and short term reversal.

Regarding our earnings-related anomaly, Barber, DeGeorge, Lehavy, and Trueman (2013) suggest that uncertainty over the earnings information to be disclosed is a primary driver of the global earnings announcement premium. Thus, if the information shock reduces uncertainty, we expect that it also reduces the earnings announcement premium.

Regarding return-related anomalies, the effect of the information shock is less clear. This is because a reduction in PEAD subsequent to the information shock is consistent with the notions that (1) the information shock increases financial reporting quality, and (2) the information shock improves general market efficiency. Since the first channel is the direct channel, we expect it to have a stronger effect. A weakened earnings announcement premium will provide further support to this channel. In comparison, since the effect of the information shock on improving general 
market efficiency is an indirect one, such an effect may not necessarily be strong enough to weaken the other anomalies.

We define our variables for the earnings-related anomaly as follows. The dependent variable is the natural $\log$ of one plus the raw return for firm $i$ in country $j$ during month $t$. ExpAnn is an indicator variable equal to one if firm $i$ in country $j$ is expected to announce annual earnings during month $t$. Expected earnings announcement date in year $t$ is based on the earnings announcement date in year $t$ - 1 . Column (1) of Table 11 shows a significant negative coefficient on ExpAnn $\times$ Post $\times$ Treatment, indicating that the treatment sample experiences a reduction in the earnings announcement premium relative to the benchmark sample after the information shock.

For our return-related anomalies, we define our variables as follows. For our analysis of the return momentum, the dependent variable is the six-month buy-and-hold return of firm $i$ in country $j$ during month $[\mathrm{t}, \mathrm{t}+5]$. Lag return is the quintile rank of six-month buy-and-hold return of firm $i$ in country $j$ during month $[\mathrm{t}-7, \mathrm{t}-2]$. The quintile rank of Lag return is further scaled to be between zero and one. For our analysis of the short-term return reversal after the information shock, the dependent variable is the raw return for firm $i$ in country $j$ during week $t$. Lag return is the quintile rank of weekly return of firm $i$ in country $j$ during week $t$-2. The quintile rank of Lag return is also further scaled to be between zero and one.

The results in Columns (2) and (3) of Table 11 show that the coefficients on Lag return $\times$ Post $\times$ Treatment are both insignificant, indicating no changes in these efficiency measures subsequent to the information shock. ${ }^{19}$ Thus, we conclude that the information shock mainly affects the market efficiency measures related to financial reporting quality.

\footnotetext{
${ }^{19}$ Untabulated results using the remaining non-trading-based efficiency measures in Griffin, Kelly, and Nardari (2010), namely variance rations and delay, also indicate no significant changes subsequent to the information shock.
} 


\section{Conclusion}

Despite extensive U.S. evidence on PEAD, international evidence is scarce and inconclusive. The mandatory adoption of IFRS by thousands of global companies in 2005 is an exogenous and unprecedented regulatory change in non-U.S. firms' financial reporting, which provides a unique opportunity to shed light on the underlying reasons of PEAD worldwide.

Using a difference-in-differences design, we find that our treatment firms experience a decrease in PEAD subsequent to the information shock. In addition, we find that this effect is more pronounced among firms with less distraction, more sophisticated investors, lower transaction costs, and lower arbitrage risks. These results are consistent with the explanation of PEAD being driven by limited investor attention and limits to arbitrage. We further find that the decrease in PEAD subsequent to the information shock is greater among firms with greater changes in financial reporting, an increase in analyst forecast accuracy and institutional ownership, or a reduction in limits of arbitrage. Overall, by combining an exogenous information shock with a difference-in-differences approach, our paper provides supporting evidence to the mispricing explanation of PEAD, in particular the limited attention hypothesis, in an international setting. 


\section{References}

Acker, E., and N.W. Duck. 2009. On the Reliability of I/B/E/S Earnings Announcement Dates and Forecasts. Working paper. University of Bristol.

Ahmed, A. S., M. Neel, and D. Wang. 2013. Does Mandatory Adoption of IFRS Improve Accounting Quality? Contemporary Accounting Research 30: 1344-1372.

Amihud, Y. 2002. Illiquidity and Stock Returns: Cross-section and Time-series Effects. Journal of Financial Markets 5: 31-56.

Amihud, Y., A. Hameed, W. Kang, and H. Zhang. 2013. The Illiquidity Premium: International Evidence. Working paper, NYU.

Ang, A., R. Hodrick, Y. Xing, and W. Zhang. 2009. High Idiosyncratic Volatility and Low Returns: International and Further U.S. Evidence. Journal of Financial Economics 91: 1-23.

Angrist, J., and A. B. Krueger. 2001. Instrumental Variables and the Search for Identification: From Supply and Demand to Natural Experiments. Journal of Economic Perspectives 15: 69-85. Ariff, M., A. Loh, and P. Chew. 1997. The Impact of Accounting Earnings Disclosures on Stock Prices in Singapore. Asia Pacific Journal of Management 14: 17-29.

Armstrong, C., M. Barth, A. Jagolinzer, and E. Riedl. 2010. Market Reaction to the Adoption of IFRS in Europe. Accounting Review 85: 31-61.

Bae, K.H., R. Stulz, and H. Tan. 2008. Do Local Analysts Know More? A Cross-country Study of the Performance of Local Analysts and Foreign Analysts. Journal of Financial Economics 88: $581-606$.

Baily, W., G.A. Karolyi, and C. Salva. 2006. The Economic Consequences of Increased Disclosure: Evidence from International Cross-listings. Journal of Financial Economics 81: 175-213. 
Barber, B., E. DeGeorge, R. Lehavy, and B. Trueman. 2013. The Earnings Announcement Premium around the Globe. Journal of Financial Economics 108: 118-138.

Barberis, N., A. Shleifer, and R.W. Vishny. 1998. A Model of Investor Sentiment. Journal of Financial Economics 49: 307-343.

Becker, G. 1968. Crime and Punishment: An Economic Approach. Journal of Political Economy 76: 169-217.

Bernard, V. L., and J. Thomas. 1989. Post-earnings-announcement Drift: Delayed Price Response or Risk Premium? Journal of Accounting Research 27: 1-48.

- 1990. Evidence that Stock Prices do not Fully Reflect the Implications of Current Earnings for Future Earnings. Journal of Accounting and Economics 13: 305-340.

Byard, D., Y. Li, and Y. Yu. 2011. The Effect of Mandatory IFRS Adoption on Financial Analysts' Information Environment. Journal of Accounting Research 49: 69-96.

Campbell, J. 1996. Understanding Risk and Return. Journal of Political Economy 104: 298-345.

Chordia, T., A. Goyal, G. Sadka, R. Sadka, and L. Shivakumar. 2009. Liquidity and the Postearnings-announcement Drift. Financial Analysts Journal 65: 18-32.

Christensen, H., L. Hail, and C. Leuz. 2013. Mandatory IFRS Reporting and Changes in Enforcement. Journal of Accounting and Economics 56: 147-177.

Covrig, V., M. DeFond, and M. Hung. 2007. Home Bias, Foreign Mutual Fund Holdings, and the Voluntary Adoption of International Accounting Standards. Journal of Accounting Research 45: $41-70$.

Daniel, K., D. Hirshleifer, and A. Subrahmanyam. 1998. Investor Psychology and Security Market Under- and Overreactions. Journal of Finance 53: 1839-1885.

- 2001. Overconfidence, Arbitrage, and Equilibrium Asset Pricing. Journal of Finance 56: $921-965$. 
Daniel, K., and T. Moskowitz. 2013 Momentum Crashes. Working paper, Columbia Business School and University of Chicago.

Daske, H., L. Hail, C. Leuz, and R. Verdi. 2008. Mandatory IFRS Reporting around the World: Early Evidence on the Economic Consequences. Journal of Accounting Research 46: 1085-1142.

DeFond, M., X. Hu, M. Hung, and S. Li. 2011. The Impact of Mandatory IFRS Adoption on Foreign Mutual Fund Ownership: The Role of Comparability. Journal of Accounting and Economics 51: 240-258.

DellaVigna, S., and J.M. Pollet. 2009. Investor Inattention and Friday Earnings Announcements. Journal of Finance 64: 709-749.

Deloitte. 2010. IFRS in Your Pocket. Deloitte Touche Tohmatsu.

Diamond, D., and R. Verrecchia. 1991. Disclosure, Liquidity, and the Cost of Capital. Journal of Finance 46: 1325-1360.

Fama, E. F. 1998. Market Efficiency, Long-term Returns, and Behavioral Finance. Journal of Financial Economics 49: 283-306.

Fama, E., and K. French. 1998. Value versus Growth: The International Evidence. Journal of Finance 53: 1975-1999.

Forner, C., and S. Sanabria. 2010. Post-earnings-announcement Drift in Spain and Behavioral Finance Models. European Accounting Review 19: 775-815.

Francis, J., R. LaFond, P. Olsson, and K. Schipper. 2007. Information Uncertainty and Postearnings-announcement Drift. Journal of Business, Finance \& Accounting 34: 403-433.

Frazzini A. and L.H. Pedersen. 2014. Betting Against Beta. Journal of Financial Economics 111: $1-25$.

Greenstone, M., P. Oyer, and A. Vissing-Jorgensen. 2006. Mandated Disclosure, Stock Returns, and the 1964 Securities Acts Amendments. Quarterly Journal of Economics 121: 399-460. 
Griffin, J., N. Hirschey, and P. Kelly. 2011. How Important is the Financial Media in Global Markets? Review of Financial Studies 24: 3941-3992.

Griffin, J., X. Ji, and J. Martin. 2003. Momentum Investing and Business Cycle Risk: Evidence from Pole to Pole. Journal of Finance 58: 2515-2547.

Griffin, J, P. Kelly, and F. Nardari. 2010. Do Market Efficiency Measures Yield Correct Inferences? A Comparison of Developed and Emerging Markets. Review of Financial Studies 23: $3225-3277$.

Healy, P., and K. Palepu. 2001. Information Asymmetry, Corporate Disclosure, and the Capital Markets: A Review of the Empirical Disclosure Literature. Journal of Accounting and Economics 31: $405-440$.

Hew, D., L. Skerratt, N. Strong, and M. Walker. 1996. Post-earnings-announcement Drift: Some Preliminary Evidence for the UK. Accounting and Business Research 26: 283-293.

Hirshleifer, D. 2001. Investor Psychology and Asset Pricing. Journal of Finance 56: 1533-1598.

Hirshleifer, D., S. S. Lim, and S. H. Teoh. 2009. Driven to Distraction: Extraneous Events and Underreaction to Earnings News. Journal of Finance 64: 2289-2325.

- 2011. Limited Investor Attention and Stock Market Misreactions to Accounting Information. Review of Asset Pricing Studies 1: 35-73.

Hirshleifer, D., and S. H. Teoh. 2003. Limited Attention, Information Disclosure, and Financial Reporting. Journal of Accounting and Economics 36: 337-386.

Hong, H., M. Hung, and G. Lobo. 2014. The Impact of Mandatory IFRS Adoption on IPOs in Global Capital Markets. Accounting Review 89: 1365-1397.

IASB. 1989. Framework for the Preparation and Presentation of Financial Statements. International Accounting Standards Board. 
— 2008. Exposure Draft of an Improved Conceptual Framework for Financial Reporting. International Accounting Standards Board.

Kaufmann, D., A. Kraay, and M. Mastruzzi. 2007. Governance Matters VI: Aggregate and Individual Governance Indicators 1996-2006. Washington, DC: The World Bank.

Ke, B., and S. Ramalingegowda. 2005. Do Institutional Investors Exploit the Post-earnings Announcement Drift? Journal of Accounting and Economics 39: 25-53.

Kimbrough, M. D. 2005. The Effect of Conference Calls on Analyst and Market Underreaction to Earnings Announcements. Accounting Review 80: 189-219.

Kumar, K. 2009. Hard-to-Value Stocks, Behavioral Biases, and Informed Trading. Journal of Financial and Quantitative Analysis 44:1375-1401.

Lam, F.Y., and K.C. Wei. 2011. Limits-to-arbitrage, Investment Frictions, and the Asset Growth Anomaly. Journal of Financial Economics 102: 127-149.

Landsman, W., E. Maydew, and J. Thornock. 2012. The Information Content of Annual Earnings Announcements and Mandatory Adoption of IFRS. Journal of Accounting and Economics 53: 3454.

La Porta R., F. Lopez-de-Silanes, A. Shleifer, and R.W. Vishny. 1997. Legal Determinants of External Finance. Journal of Finance 52: 1131-1150.

Leuz, C., D. Nanda, and P. Wysocki. 2003. Earnings Management and Investor Protection: An International Comparison. Journal of Financial Economics 69: 505-527.

McLean, R.D., J. Pontiff, and A. Watanabe. 2009. Share Issuance and Cross-sectional Returns: International Evidence. Journal of Financial Economics 94: 1-17.

Mendenhall, R. 2004. Arbitrage Risk and Post-earnings-announcement Drift. Journal of Business 77: 875-894.

Petersen, M. A. 2009. Estimating Standard Errors in Finance Panel Data Sets: Comparing 42 
Approaches. Review of Financial Studies 22: 435-480.

Pincus, M., S. Rajgopal, and M. Venkatachalam. 2007. The Accrual Anomaly: International Evidence. Accounting Review 82: 169-203.

Rouwenhorst, K.G. 1998. International Momentum Strategies. Journal of Finance 53: 267-284.

Shleifer, A., and R.W. Vishny. 1997. The Limits of Arbitrage. Journal of Finance 52: 35-55.

Stigler, G. 1964. Public Regulation of the Securities Market. Journal of Business 37: 117-142.

Tan, H., S. Wang, and M. Welker. 2011. Analyst Following and Forecast Accuracy after Mandated IFRS Adoptions. Journal of Accounting Research 49: 1307-1357.

Titman, S., K.C. J. Wei, and F. Xie. 2013. Market Development and the Asset Growth Effect: International Evidence. Journal of Financial and Quantitative Analysis 48: 1405-1432.

Truong, C. 2010. Post Earnings Announcement Drift and the Roles of Drift-enhanced Factors in New Zealand. Pacific-Basin Finance Journal 18: 139-157.

Van Huffel, G., P. Joos, and H. Ooghe. 1996. Semi-annual Earnings Announcements and Market Reaction: Some Recent Findings for a Small Capital Market. European Accounting Review 5: 693-713.

Vega, C. 2006. Stock Price Reaction to Public and Private Information. Journal of Financial Economics 82: 103-133.

Watanabe, A., Y. Xu, T. Yao, and T. Yu. 2013. The Asset Growth Effect: Insights from International Equity Markets. Journal of Financial Economics 108: 529-563.

Zhang, X. 2006. Information Uncertainty and Stock Returns. Journal of Finance 86: 105-137. 


\section{Appendix A}

An example of additional disclosure and reporting changes during earnings announcements subsequent to mandatory IFRS adoption: Finnair (Finland)

\begin{tabular}{|c|c|c|}
\hline $\begin{array}{l}\text { Earnings announcement } \\
\text { release }\end{array}$ & $\begin{array}{l}2004 \\
\text { (pre-shock) }\end{array}$ & $\begin{array}{l}2006 \\
\text { (post-shock) }\end{array}$ \\
\hline Earnings announcement date & February 17,2005 & February 6, 2007 \\
\hline Fiscal year & 2004 & 2006 \\
\hline Financial reporting standards & $\begin{array}{l}\text { Finnish Financial } \\
\text { Reporting standards }\end{array}$ & IFRS \\
\hline $\begin{array}{l}\text { Number of words in the main } \\
\text { body of the earnings release }\end{array}$ & 4,826 & 6,848 \\
\hline $\begin{array}{l}\text { Consolidated income } \\
\text { statement }\end{array}$ & Yes & $\begin{array}{l}\text { Yes, and further includes disclosure } \\
\text { of earnings per shares (both basic and } \\
\text { diluted) }\end{array}$ \\
\hline Consolidated balance sheet & Yes & $\begin{array}{l}\text { Yes, and includes additional items in } \\
\text { the following major balance sheet } \\
\text { categories: (1) non-current assets: } \\
\text { investment in associates and deferred } \\
\text { tax receivables, (2) long-term } \\
\text { liabilities: financial liabilities, and } \\
\text { pension obligations, (3) short-term } \\
\text { liabilities: current income tax } \\
\text { liabilities, reserves, financial } \\
\text { liabilities, and trade payables and } \\
\text { other liabilities. }\end{array}$ \\
\hline $\begin{array}{l}\text { Consolidated cash flow } \\
\text { Statement }\end{array}$ & Yes & $\begin{array}{l}\text { Yes, and further includes a } \\
\text { breakdown of changes in working } \\
\text { capital (i.e., trade and other } \\
\text { receivables, inventory, and accounts } \\
\text { payables and other obligations) }\end{array}$ \\
\hline Segment disclosure & Yes & $\begin{array}{l}\text { Yes, and further includes geographic } \\
\text { segment disclosure of sales revenue }\end{array}$ \\
\hline $\begin{array}{l}\text { Statement of changes in } \\
\text { shareholders' equity }\end{array}$ & No & Yes \\
\hline
\end{tabular}

Source: http://www.finnairgroup.com/mediaen/mediaen_7.html?Id=rss_49881.html (for the 2004 release) and http://www.finnairgroup.com/mediaen/mediaen_7.html?Id=rss_175991.html (for the 2006 release). 


\title{
Appendix B \\ Variable definitions
}

\author{
Variables of interest \\ POSTRET \\ Three-month (+2 to +64 trading days following the announcement) buy- \\ and-hold return adjusted for contemporaneous buy-and-hold value-weighted \\ market index return. \\ SUE \\ Actual earnings per share minus last analyst consensus at least three days \\ before the earnings announcement, scaled by stock price at least six but not \\ more than 12 days prior to earning announcement. \\ QSUE \\ PEAD \\ Scaled quintile rank of $S U E$, ranging from zero to one, of every country- \\ year.

SUE. \\ POST Indicator variable for firm-years after mandatory IFRS adoption. \\ Treatment Indicator variable for firms mandatorily adopting IFRS subsequent to 2005.

\section{Control variables} \\ SIZE \\ $M T B$ \\ BETA \\ PRERET \\ COUNTRY \\ INDUSTRY \\ YEAR \\ Natural logarithm of market value in millions of US dollars at the end of the \\ fiscal year. \\ Ratio of market value of equity to book value of equity at the end of the \\ fiscal year. \\ Estimate on market returns in a market model regression for firms with daily \\ returns in the 250 trading days before the earnings announcement. \\ Return momentum measured as three-month buy-and-hold return adjusted \\ for country-level market turn (skipping one month) before the earnings \\ announcement. \\ Indicators for countries. \\ Indicators for industry membership based on Campbell (1996). \\ Indicators for years.
}

Conditional variables

Concurrent earnings announcements

Institutional holdings
The number of concurrent earnings announcements issued by firms from other industries but in the same region.

Total number of shares owned by institutional investors divided by shares outstanding.

AMIHUD
The mean value of absolute daily returns divided by daily dollar trading volume (in millions of US dollars) during -252 to -2 trading days before the earnings announcement. 


\section{Appendix B, continued}

IVOL

Capital market development

Rule of law

Earnings management Aggregate earnings management index from Leuz, Nanda, and Wysocki (2003). Higher values indicate lower earnings management.

\section{Others}

$\triangle G A A P 1$

$\triangle G A A P 2$

$F E_{t}$

$F E_{t+1}$

Standard deviation of the residual values from the time-series market model: $R_{i t}=b_{0}+b_{1} R_{M t}+e_{i t}$, where $R_{i t}$ is the daily stock return and $R_{M t}$ is the daily value-weighted market index return. The model is estimated during 252 to -2 trading days before the earnings announcement.

The mean rank of three variables used in La Porta, Lopez-de-Silanes, Shleifer, and Vishny (1997): (1) the ratio of aggregate stock market capitalization held by minorities to the gross national product, (2) the number of listed domestic firms relative to the population, and (3) the number of IPOs relative to the population. Each variable is ranked such that a higher score indicates greater development.

Mean value of rule of law index during 2006 and 2007 from Kaufmann, Kraay, and Mastruzzi (2007). Higher values indicate stronger rule of law.

A dummy variable equal to one if the number of restated accounts of a treatment firm is above the $25^{\text {th }}$ percentile of all treatment firms. The ten most frequently restated accounts include seven balance sheet items: shortterm investment, PPE, intangible assets, leases, deferred taxes, provisions, and post-retirement benefits, and three income statement items: revenue, cost of goods sold, and discontinued operation.

A dummy variable equal to one if a treatment firm is from a countryindustry with the aggregate accounting change score above the $25^{\text {th }}$ percentile of 199 country-industries of the treatment sample.

Mean value of analyst forecast errors for year $t$, where the forecast is the most recent forecast issued by each analyst within 180 trading days before year $t$ 's annual earnings announcement and the forecast error is calculated as actual earnings minus forecasted earnings, scaled by stock price at the end of year $t$.

Mean value of analyst forecast errors for year $t+1$, where the forecast is the first forecast issued by each analyst within 64 trading days after year $t$ 's annual earnings announcement and the forecast error is calculated as actual earnings minus forecasted earnings, scaled by stock price at the end of year $t$. 
Table 1

Sample distribution

\begin{tabular}{|c|c|c|c|}
\hline \multirow[b]{2}{*}{ Country } & \multirow[t]{2}{*}{ No. of firms } & \multicolumn{2}{|c|}{ No. of firm-years } \\
\hline & & pre-shock & post-shock \\
\hline \multicolumn{4}{|c|}{ Treatment countries } \\
\hline Australia & 213 & 381 & 380 \\
\hline Belgium & 41 & 69 & 75 \\
\hline Denmark & 53 & 94 & 96 \\
\hline Finland & 69 & 127 & 133 \\
\hline France & 197 & 359 & 347 \\
\hline Germany & 126 & 230 & 229 \\
\hline Greece & 52 & 100 & 94 \\
\hline Hong Kong & 167 & 290 & 308 \\
\hline Ireland & 26 & 22 & 49 \\
\hline Italy & 91 & 163 & 165 \\
\hline Netherlands & 78 & 143 & 141 \\
\hline Norway & 63 & 108 & 118 \\
\hline Philippines & 22 & 42 & 22 \\
\hline South Africa & 75 & 136 & 123 \\
\hline Spain & 79 & 146 & 150 \\
\hline Sweden & 101 & 186 & 192 \\
\hline Switzerland & 79 & 150 & 143 \\
\hline UK & 389 & 675 & 676 \\
\hline Sub-total & 1,921 & 3,421 & 3,441 \\
\hline \multicolumn{4}{|c|}{ Benchmark countries } \\
\hline Brazil & 54 & 90 & 97 \\
\hline Canada & 347 & 597 & 576 \\
\hline China & 107 & 135 & 188 \\
\hline India & 95 & 160 & 178 \\
\hline Indonesia & 48 & 80 & 91 \\
\hline Japan & 710 & 1,257 & 1,268 \\
\hline Malaysia & 129 & 219 & 214 \\
\hline Mexico & 29 & 48 & 54 \\
\hline South Korea & 45 & 68 & 79 \\
\hline Taiwan & 87 & 137 & 158 \\
\hline Thailand & 117 & 211 & 210 \\
\hline US & 2,281 & 4,115 & 4,028 \\
\hline Sub-total & 4,049 & 7,117 & 7,141 \\
\hline Full sample & 5,970 & 10,538 & 10,582 \\
\hline
\end{tabular}

The full sample consists of 1,921 firms from 18 treatment countries and 4,049 firms from 12 benchmark countries during the four-year window surrounding mandatory IFRS adoption dates. Pre-shock refers to the two years before mandatory IFRS adoption (i.e., [-2,-1]), and Post-shock refers to the two years after mandatory IFRS adoption (i.e., [1, 2], not including the first mandatory IFRS adoption year). To make sure that any change in post-earnings announcement drift is based on the same set of underlying firms, we require a firm to be present at least once in both the pre-shock period and the post-shock period. For firms meeting the above requirement, we require a country to have at least 20 observations in each year during both the preshock and post-shock periods. 
Table 2

Descriptive statistics and correlations

Panel A: Descriptive statistics on firm characteristics

\begin{tabular}{lcccccc}
\hline & \multicolumn{2}{c}{ Treatment firms (N=6,862) } & \multicolumn{2}{c}{ Benchmark firms $(\mathbf{N = 1 4 , 2 5 8 )}$} \\
\cline { 2 - 7 } Variable & Mean & Median & Std. dev. & Mean & Median & Std. dev. \\
\hline POSTRET & -0.0092 & -0.0138 & 0.1338 & -0.0041 & -0.0106 & 0.1589 \\
SUE & 0.0017 & 0.0014 & 0.0373 & 0.0231 & 0.0003 & 1.7333 \\
SIZE & 7.1450 & 7.0006 & 1.6745 & 7.2326 & 7.1077 & 1.5687 \\
MTB & 2.8178 & 2.1560 & 3.5443 & 2.8914 & 2.1276 & 2.9537 \\
BETA & 0.8308 & 0.8213 & 0.3367 & 1.0316 & 0.9829 & 0.4862 \\
PRERET & 0.0052 & 0.0053 & 0.1342 & 0.0031 & -0.0107 & 0.1658 \\
\hline
\end{tabular}

Panel B: Correlation matrix for the treatment sample $(N=6,862)$

\begin{tabular}{|c|c|c|c|c|c|c|}
\hline \multirow[b]{2}{*}{ Variable } & \multicolumn{2}{|c|}{ Key variables } & \multicolumn{4}{|c|}{ Control variables } \\
\hline & POSTRET & SUE & SIZE & MTB & BETA & PRERET \\
\hline POSTRET & & $0.0219 * * *$ & $0.0250 * *$ & -0.0023 & $-0.0399 * * *$ & $0.0587 * * *$ \\
\hline SUE & $0.0518 * * *$ & & $0.0661 * * *$ & -0.0059 & -0.0026 & $0.0401 * * *$ \\
\hline SIZE & $0.0402 * * *$ & $0.0519 * * *$ & & $0.0755 * * *$ & $0.4003 * * *$ & $-0.0295 * *$ \\
\hline MTB & $0.0288 * *$ & $-0.0637 * * *$ & $0.1513 * * *$ & & $0.0495 * * *$ & $0.0482 * * *$ \\
\hline BETA & $-0.0408 * * *$ & -0.0048 & $0.4286 * * *$ & $0.0943 * * *$ & & $-0.0508 * * *$ \\
\hline PRERET & $0.0497 * * *$ & $0.0958 * * *$ & -0.0082 & $0.0620 * * *$ & $-0.0584 * * *$ & \\
\hline
\end{tabular}

Panel B: Correlation matrix for the benchmark sample $(N=14,258)$

\begin{tabular}{|c|c|c|c|c|c|c|}
\hline \multirow[b]{2}{*}{ Variable } & \multicolumn{2}{|c|}{ Key variables } & \multicolumn{4}{|c|}{ Control variables } \\
\hline & POSTRET & SUE & SIZE & MTB & BETA & PRERET \\
\hline POSTRET & & $0.0837 * * *$ & $0.0575 * * *$ & $-0.0121 * *$ & $-0.0241 * * *$ & $0.0444 * * *$ \\
\hline SUE & $0.0819 * * *$ & & 0.0060 & -0.0041 & -0.0001 & 0.0104 \\
\hline SIZE & $0.0781 * * *$ & $0.0570 * * *$ & & $0.1499 * * *$ & $0.0677 * * *$ & $0.0761 * * *$ \\
\hline MTB & 0.0121 & $0.0201 * *$ & $0.2133 * * *$ & & $0.0647 * * *$ & $0.1070 * * *$ \\
\hline BETA & $-0.0311 * * *$ & $0.0166^{* *}$ & $0.0782 * * *$ & $0.1193 * * *$ & & $-0.0360 * * *$ \\
\hline PRERET & $0.0433 * * *$ & $0.1037 * * *$ & $0.0987 * * *$ & $0.1305 * * *$ & $-0.0461 * * *$ & \\
\hline
\end{tabular}

Panel A of Table 2 presents the descriptive statistics for the main variables. POSTRET is the three-month (+2 to +64 trading days following the announcement) buy-and-hold return, adjusted for contemporaneous buy-and-hold value-weighted market index return after the earnings announcement. SUE is actual earnings per share minus the last analyst consensus at least three days before the earnings announcement, scaled by stock price at least 6 but not more than 12 days prior to the earnings announcement. SIZE is logarithm of market value of equity in millions of US dollars. $M T B$ is the ratio of market value of equity to book value of equity. BETA is estimated using a market model regression for firms with a daily return one year before the earnings announcement. PRERET is the threemonth ( -85 to -23 trading days before the announcement) buy-and-hold return adjusted for the contemporaneous buy-and-hold value-weighted market index return before the earnings announcement. Panels B and C present the correlations for the treatment and benchmark samples, respectively. Pearson and Spearman correlation coefficients are reported above and below the diagonal, respectively. $* * *, * *$, and * indicate significance at the $1 \%, 5 \%$, and $10 \%$ levels, respectively. 
Table 3

Univariate analysis and country-level regression of post-earnings-announcement drift

Panel A: Univariate Analysis

\begin{tabular}{|c|c|c|c|}
\hline & PEAD, pre-shock & PEAD, post-shock & Difference \\
\hline Country & (1) & $(2)$ & (3) \\
\hline Australia & $0.0601 * *$ & $0.0249 *$ & $-0.0352 * *$ \\
\hline Belgium & 0.0100 & 0.0327 & 0.0227 \\
\hline Denmark & 0.0179 & 0.0028 & -0.0151 \\
\hline Finland & -0.0336 & $0.0240^{*}$ & $0.0576^{*}$ \\
\hline France & $0.0440 * *$ & 0.0006 & $-0.0434 * *$ \\
\hline Germany & $0.0390^{*}$ & 0.0196 & $-0.0194 * *$ \\
\hline Greece & $0.0640^{*}$ & 0.0180 & $-0.0460 *$ \\
\hline Hong Kong & $0.0317 *$ & $0.0134 * *$ & -0.0183 \\
\hline Ireland & 0.0596 & 0.0201 & -0.0395 \\
\hline Italy & 0.0274 & $0.0109 *$ & -0.0165 \\
\hline Netherlands & $0.0230 * *$ & 0.0006 & $-0.0224 *$ \\
\hline Norway & -0.0019 & -0.0402 & $-0.0383^{*}$ \\
\hline Philippines & 0.0497 & 0.0225 & -0.0272 \\
\hline South Africa & $0.0529 * *$ & 0.0093 & $-0.0436 * *$ \\
\hline Spain & -0.0012 & 0.0282 & 0.0294 \\
\hline Sweden & $0.0554 * *$ & $0.0191 *$ & $-0.0363 * *$ \\
\hline Switzerland & $0.0171^{*}$ & 0.0041 & $-0.0130 *$ \\
\hline U.K. & $0.0362 * *$ & $0.0122 * *$ & $-0.0240^{* *}$ \\
\hline Treatment countries & $0.0244 * * *$ & 0.0106 & $-0.0138 * * *$ \\
\hline Brazil & -0.0337 & $0.0541^{*}$ & 0.0878 \\
\hline Canada & $0.0528 * * *$ & $0.0765^{* *}$ & $0.0236 *$ \\
\hline China & $0.0662 *$ & 0.0491 & -0.0171 \\
\hline India & -0.0177 & 0.0311 & 0.0489 \\
\hline Indonesia & 0.0179 & 0.0427 & 0.0248 \\
\hline Japan & $0.0455 * * *$ & $0.0529 * * *$ & 0.0074 \\
\hline Malaysia & $0.0500 * *$ & $0.0700 * *$ & $0.0201 *$ \\
\hline Mexico & $0.0768 * * *$ & 0.0174 & -0.0594 \\
\hline South Korea & 0.0312 & 0.0589 & 0.0277 \\
\hline Taiwan & $0.0212 * *$ & $0.0416^{* *}$ & 0.0205 \\
\hline Thailand & $0.0801 * * *$ & $0.0255^{*}$ & $-0.0546^{* *}$ \\
\hline U.S. & $0.0157 * *$ & $0.0405^{* * *} *$ & $0.0248 * *$ \\
\hline Benchmark countries & $0.0280 * * *$ & $0.0415 * * *$ & $0.0135 * *$ \\
\hline $\begin{array}{l}\text { Difference, treatment versus } \\
\text { benchmark countries }\end{array}$ & -0.0036 & $-0.0309 * * *$ & $-0.0273 * * * *$ \\
\hline
\end{tabular}

Panel B: Country-level regression analysis

\begin{tabular}{lllcccc}
\hline & Intercept & Treatment & POST & POST $\times$ Treatment & No. of obs. & Adj. $\mathbf{R}^{2}$ \\
\hline Coefficient & $\mathbf{0 . 0 2 8 6}^{* *}$ & -0.0066 & 0.0141 & $\mathbf{- 0 . 0 2 6 3} * *$ & 118 & 0.08 \\
& $\mathbf{( 2 . 0 3 )}$ & $(-0.62)$ & $(0.96)$ & $\mathbf{( - 2 . 2 0 )}$ & & \\
\hline
\end{tabular}

Panel A of this table presents PEAD by country and by period. Panel B presents a country-level regression, with robust $t$-statistics clustered by country reported in parentheses. The dependent variable is the country-year PEAD. Country-year PEAD is measured by the difference in the mean POSTRET of firms in the top quintile and the bottom quintile of earnings surprises. $* * *, * * *$ indicate significance at the $1 \%, 5 \%$ and $10 \%$ levels (two-tailed), respectively. 
Table 4

The effects of the information shock on post-earnings-announcement drift

Panel A: [-2, +2] periods, based on 2005 mandatory adopters

\begin{tabular}{|c|c|c|c|c|c|c|}
\hline \multirow[b]{2}{*}{ Variables } & \multicolumn{2}{|c|}{ Treatment sample } & \multicolumn{2}{|c|}{ Benchmark sample } & \multicolumn{2}{|c|}{ Full sample } \\
\hline & (1) & $(2)$ & (3) & (4) & $(5)$ & (6) \\
\hline \multirow[t]{2}{*}{ QSUE } & $0.0296 * * *$ & $0.0281 * * *$ & $0.0323 * * *$ & $0.0312 * * *$ & $0.0322 * * *$ & $0.0312 * * *$ \\
\hline & $(4.38)$ & $(4.34)$ & $(3.79)$ & $(4.03)$ & $(3.92)$ & $(4.15)$ \\
\hline \multirow[t]{2}{*}{ POST $\times Q S U E$} & $-0.0276 * * *$ & $-\mathbf{0 . 0 2 7 5} * * *$ & $0.0086^{*}$ & 0.0062 & $0.0090 *$ & 0.0063 \\
\hline & $(-3.15)$ & $(-3.11)$ & $(1.80)$ & $(1.29)$ & $(1.94)$ & $(1.36)$ \\
\hline \multirow[t]{2}{*}{ POST $\times$ Treatment } & & & & & 0.0099 & 0.0086 \\
\hline & & & & & $(0.97)$ & $(0.87)$ \\
\hline \multirow[t]{2}{*}{ QSUExTreatment } & & & & & -0.0005 & -0.0015 \\
\hline & & & & & $(-0.04)$ & $(-0.13)$ \\
\hline \multirow[t]{2}{*}{ POST×QSUExTreatment } & & & & & $\mathbf{- 0 . 0 3 8 5} * * *$ & $-0.0353 * * *$ \\
\hline & & & & & $(-3.59)$ & $(-3.31)$ \\
\hline \multirow[t]{2}{*}{ SIZE } & & $0.0046 * * *$ & & $0.0043 * * *$ & & $0.0044 * * *$ \\
\hline & & $(3.17)$ & & $(4.54)$ & & $(5.86)$ \\
\hline \multirow[t]{2}{*}{ MTB } & & -0.0003 & & $-0.0015 * *$ & & $-0.0010 * *$ \\
\hline & & $(-0.74)$ & & $(-2.43)$ & & $(-2.25)$ \\
\hline \multirow[t]{2}{*}{ BETA } & & $-0.0220 * * *$ & & $-0.0176 * * *$ & & $-0.0183 * * *$ \\
\hline & & $(-4.31)$ & & $(-2.78)$ & & $(-3.41)$ \\
\hline \multirow[t]{2}{*}{ PRERET } & & $0.0388 * *$ & & $0.0305^{* * *}$ & & $0.0324 * * *$ \\
\hline & & $(2.55)$ & & $(2.64)$ & & $(3.63)$ \\
\hline Fixed effects & \multicolumn{6}{|c|}{ Country, industry, year } \\
\hline No. of obs. & 6,862 & 6,862 & 14,258 & 14,258 & 21,120 & 21,120 \\
\hline Adj. $R^{2}$ & 0.05 & 0.05 & 0.04 & 0.04 & 0.04 & 0.04 \\
\hline
\end{tabular}


Table 4, continued

Panel B: Robustness tests for concurrent events

\begin{tabular}{|c|c|c|c|c|c|c|}
\hline & $\begin{array}{c}\text { European } \\
\text { firms only }\end{array}$ & $\begin{array}{c}\text { Non-European } \\
\text { firms only }\end{array}$ & $\begin{array}{c}\text { Countries with } \\
\text { concurrent } \\
\text { enforcement } \\
\text { changes }^{\mathbf{a}}\end{array}$ & $\begin{array}{c}\text { Countries } \\
\text { without } \\
\text { concurrent } \\
\text { enforcement } \\
\text { changes } \\
\end{array}$ & $\begin{array}{c}\text { Non-2005 IFRS } \\
\text { adopters, } \\
\text { Treatment firms } \\
\text { only }^{\mathbf{b}} \\
\end{array}$ & $\begin{array}{c}\text { Benchmark with } \\
\text { voluntary adopters }\end{array}$ \\
\hline Variables & (1) & (2) & (3) & (4) & (5) & (6) \\
\hline QSUE & $\begin{array}{l}0.0313^{* * *} \\
(4.10)\end{array}$ & $\begin{array}{l}0.0310^{* * *} \\
(4.14)\end{array}$ & $\begin{array}{l}0.0313 * * * \\
(4.07)\end{array}$ & $\begin{array}{l}0.0310^{* * * *} \\
(4.15)\end{array}$ & $\begin{array}{l}0.299^{* * * *} \\
(4.15)\end{array}$ & $\begin{array}{l}0.0004 \\
(0.06)\end{array}$ \\
\hline POST $\times$ QSUE & $\begin{array}{l}0.0060 \\
(1.28)\end{array}$ & $\begin{array}{l}0.0065 \\
(1.40)\end{array}$ & $\begin{array}{l}0.0059 \\
(1.27)\end{array}$ & $\begin{array}{l}0.0065 \\
(1.40)\end{array}$ & $\begin{array}{l}-0.0593 * * \\
(-2.00)\end{array}$ & $\begin{array}{l}0.0283 \\
(1.22)\end{array}$ \\
\hline QSUExTreatment & $\begin{array}{l}-0.0109 \\
(-0.97)\end{array}$ & $\begin{array}{l}0.0285^{* *} \\
(2.43)\end{array}$ & $\begin{array}{l}-0.0172 \\
(-1.44)\end{array}$ & $\begin{array}{l}0.0080 \\
(0.68)\end{array}$ & & $\begin{array}{l}0.0357 * * * \\
(3.26)\end{array}$ \\
\hline POST $\times$ QSUE $\times$ Treatment & $\begin{array}{l}-0.0253 * * \\
(-2.12)\end{array}$ & $\begin{array}{l}-0.0663 * * * \\
(-5.86)\end{array}$ & $\begin{array}{l}-0.0240 * * \\
(-2.53)\end{array}$ & $\begin{array}{l}-0.0424 * * * \\
(-3.40)\end{array}$ & & $\begin{array}{l}-0.0553 * * \\
(-2.41)\end{array}$ \\
\hline $\begin{array}{l}\text { Control variables } \\
\text { Fixed effects }\end{array}$ & & \multicolumn{4}{|c|}{ Yes } & \\
\hline
\end{tabular}


Table 4, continued

Panel C: Robustness tests for identification issues of DID approach

\begin{tabular}{|c|c|c|c|c|}
\hline & $\begin{array}{c}\text { Pseudo adoption } \\
\text { period, } \\
{[2001-2002] \text { vs. }} \\
{[2003-2004]} \\
\end{array}$ & $\begin{array}{c}\text { Pseudo adoption } \\
\text { period, } \\
{[2006,2007] \text { vs. }} \\
{[2008,2009]} \\
\end{array}$ & $\begin{array}{c}\text { Developed } \\
\text { markets }\end{array}$ & $\begin{array}{c}\text { Emerging } \\
\text { markets }\end{array}$ \\
\hline Variables & (1) & (2) & (3) & (4) \\
\hline QSUE & $\begin{array}{l}0.0148 * * * \\
(3.28)\end{array}$ & $\begin{array}{l}0.0206^{* *} \\
(2.58)\end{array}$ & $\begin{array}{l}0.0299 * * * \\
(3.74)\end{array}$ & $\begin{array}{l}0.0392 * * * \\
(2.77)\end{array}$ \\
\hline POST $\times Q S U E$ & $\begin{array}{l}0.0095^{* *} \\
(2.10)\end{array}$ & $\begin{array}{l}0.0046 \\
(0.54)\end{array}$ & $\begin{array}{l}0.0061 \\
(1.25)\end{array}$ & $\begin{array}{l}0.0086 \\
(0.46)\end{array}$ \\
\hline POST $\times$ Treatment & $\begin{array}{l}0.0322 * * * \\
(2.86)\end{array}$ & $\begin{array}{l}0.0264 \\
(1.52)\end{array}$ & $\begin{array}{l}0.0069 \\
(0.67)\end{array}$ & $\begin{array}{l}0.0250 \\
(1.54)\end{array}$ \\
\hline QSUExTreatment & $\begin{array}{l}0.0014 \\
(0.14)\end{array}$ & $\begin{array}{l}0.0101 \\
(0.91)\end{array}$ & $\begin{array}{l}-0.0025 \\
(-0.21)\end{array}$ & $\begin{array}{l}0.0310^{*} \\
(1.94)\end{array}$ \\
\hline POST $\times Q S U E \times$ Treatment & $\begin{array}{l}-0.0070 \\
(-0.65)\end{array}$ & $\begin{array}{l}-0.0217 \\
(-1.30)\end{array}$ & $\begin{array}{l}-0.0327 * * * \\
(-2.92)\end{array}$ & $\begin{array}{l}-0.0833 * * \\
(-2.31)\end{array}$ \\
\hline $\begin{array}{l}\text { Control variables } \\
\text { Fixed effects }\end{array}$ & \multicolumn{4}{|c|}{ Yes } \\
\hline No. of obs. & 22,872 & 37,447 & 18,822 & 2,298 \\
\hline Adj. $R^{2}$ & 0.05 & 0.06 & 0.04 & 0.08 \\
\hline
\end{tabular}

This table shows the effects of the information shock on post earnings announcement drift. The dependent variable is POSTRET. See Appendix B for definitions of variables. Robust $t$-statistics clustered by country are reported in parentheses. ${ }^{* * *}, * *, *$ indicate significance at the $1 \%, 5 \%$ and $10 \%$ levels (two-tailed), respectively.

a. Countries with concurrent enforcement changes include: Finland, Germany, the Netherlands, Norway, and the U.K.

b. Non-2005 IFRS adopters includes Singapore (2003), Turkey (2006), New Zealand (2007), Pakistan (2007), Israel (2008), Brazil (2010), Canada (2011), and South Korea (2011).

c. Voluntary adopters refer to firms adopting IFRS before a firm's home country mandates the adoption. 
Table 5

The effect of improved financial reporting quality on PEAD: Alternative settings

Panel A: Sample distribution by country

\begin{tabular}{|c|c|c|c|}
\hline Country & U.S. cross-listing & $\begin{array}{c}\text { Voluntary } \\
\text { IFRS adoption }\end{array}$ & $\begin{array}{c}\text { US Segment disclosure, } \\
\text { SFAS } 131\end{array}$ \\
\hline Argentina & 18 & 0 & \\
\hline Australia & 22 & 3 & \\
\hline Austria & 0 & 36 & \\
\hline Belgium & 2 & 18 & \\
\hline Brazil & 37 & 1 & \\
\hline Canada & 203 & 2 & \\
\hline Chile & 18 & 0 & \\
\hline China & 76 & 33 & \\
\hline Colombia & 3 & 0 & \\
\hline Czech Republic & 0 & 4 & \\
\hline Denmark & 4 & 19 & \\
\hline Egypt & 0 & 2 & \\
\hline Finland & 4 & 10 & \\
\hline France & 20 & 41 & \\
\hline Germany & 16 & 155 & \\
\hline Greece & 15 & 6 & \\
\hline Hong Kong & 14 & 5 & \\
\hline Hungary & 0 & 4 & \\
\hline India & 13 & 0 & \\
\hline Indonesia & 2 & 0 & \\
\hline Ireland & 10 & 0 & \\
\hline Israel & 55 & 0 & \\
\hline Italy & 8 & 72 & \\
\hline Japan & 17 & 0 & \\
\hline Mexico & 29 & 1 & \\
\hline Netherlands & 28 & 9 & \\
\hline New Zealand & 5 & 1 & \\
\hline Norway & 4 & 2 & \\
\hline Pakistan & 0 & 2 & \\
\hline Peru & 3 & 8 & \\
\hline Portugal & 3 & 5 & \\
\hline Russia & 2 & 2 & \\
\hline Singapore & 4 & 4 & \\
\hline South Africa & 7 & 17 & \\
\hline South Korea & 9 & 0 & \\
\hline Spain & 8 & 1 & \\
\hline Sweden & 9 & 7 & \\
\hline Switzerland & 15 & 75 & \\
\hline Taiwan & 9 & 0 & \\
\hline Turkey & 1 & 61 & \\
\hline U.K. & 93 & 0 & \\
\hline Venezuela & 2 & 0 & \\
\hline U.S & 0 & 0 & 625 \\
\hline No. of firms & 788 & 606 & 625 \\
\hline
\end{tabular}


Table 5, continued

Panel B: The effect of improved financial reporting quality on PEAD in alternative settings

\begin{tabular}{|c|c|c|c|c|}
\hline \multirow[b]{3}{*}{ Variables } & \multirow{2}{*}{$\begin{array}{c}\text { U.S. } \\
\text { cross-listing } \\
\\
\text { Treatment sample } \\
{[-2,+2],} \\
1994-2012 \\
\end{array}$} & \multirow{2}{*}{$\begin{array}{c}\text { Voluntary } \\
\text { IFRS adoption } \\
\text { Treatment sample } \\
{[-2,+2]} \\
1994-2004 \\
\end{array}$} & \multicolumn{2}{|c|}{$\begin{array}{c}\text { U.S. Segment disclosure, } \\
\text { SFAS } 131\end{array}$} \\
\hline & & & $\begin{array}{c}\text { Treatment } \\
\text { sample } \\
{[1995-1996] \text { vs }} \\
{[1998-1999]} \\
\end{array}$ & $\begin{array}{c}\text { Full sample, } \\
{[1995-1996] \mathrm{v} s} \\
{[1998-1999]}\end{array}$ \\
\hline & (1) & $(2)$ & (3) & (4) \\
\hline QSUE & $\begin{array}{l}(\mathbf{0 . 0 4 5 9} * * * \\
(2.89)\end{array}$ & $\begin{array}{l}\text { 0.0.0249**** } \\
(2.74)\end{array}$ & $\begin{array}{l}\mathbf{0 . 0 2 6 0} * * * \\
(2.95)\end{array}$ & $\begin{array}{l}0.0293 * * * \\
(6.06)\end{array}$ \\
\hline Treatment & n.a. & n.a. & n.a. & $\begin{array}{l}0.0045 \\
(0.48)\end{array}$ \\
\hline QSUExTreatment & n.a. & n.a. & n.a. & $\begin{array}{l}-0.0054 \\
(-0.75)\end{array}$ \\
\hline POST $\times Q S U E$ & $\begin{array}{l}-0.0399 * * * \\
(-2.77)\end{array}$ & $\begin{array}{l}-0.0074 * * \\
(-1.99)\end{array}$ & $\begin{array}{l}-0.0265 \\
(-0.56)\end{array}$ & $\begin{array}{l}0.0054 \\
(0.30)\end{array}$ \\
\hline POST $\times$ Treatment & n.a. & n.a. & n.a. & $\begin{array}{l}0.0151 \\
(0.66)\end{array}$ \\
\hline POST $\times$ QSUE $\times$ Treatment & n.a. & n.a. & n.a. & $\begin{array}{l}-0.0299 \\
(-0.89)\end{array}$ \\
\hline Control variables & Yes & Yes & Yes & Yes \\
\hline Country fixed effects & Yes & Yes & No & No \\
\hline Industry fixed effects & Yes & Yes & Yes & Yes \\
\hline Year fixed effects & Yes & Yes & Yes & Yes \\
\hline Standard errors clustering & Country, year & Country, year & Year & Year \\
\hline $\begin{array}{l}\text { No. of total obs. } \\
\text { Adj. } R^{2}\end{array}$ & $\begin{array}{c}1,877 \\
0.09\end{array}$ & $\begin{array}{c}1,437 \\
0.07\end{array}$ & $\begin{array}{c}3,040 \\
0.05\end{array}$ & $\begin{array}{c}14,613 \\
0.03\end{array}$ \\
\hline
\end{tabular}

This table reports the effects of alternative events that expect to increase financial reporting quality on post-earningsannouncement drift, including cross-listing on the U.S. stock exchanges, voluntary adoption of IFRS, and the 1997 U.S. segment disclosure regulation, SFAS 131. Panel A reports the sample distribution of each event. Panel B reports the regression estimates for the impact of these events on PEAD. The dependent variable is POSTRET. POST is a dummy variable set to one for the period after a firm cross-lists in the U.S. (Column 1), a firm voluntarily adopts IFRS (Column 2), or the segment disclosure regulation comes into effectiveness in the U.S. (Columns 3 and 4), and zero otherwise. In Column (4), Treatment is a dummy variable indicating that a firm changes from a single-segment reporting to multiple-segment reporting upon the mandate of SFAS 131. Robust $t$-statistics clustered by country and by year are reported in parentheses in Columns (1)-(2). Robust $t$-statistics clustered by year are reported in parentheses in Columns (3)-(4). ***, **, * indicate significance at the $1 \%, 5 \%$ and $10 \%$ levels (two-tailed), respectively. 
Table 6

The effects of information shock on PEAD, conditional on firm-level characteristics

Panel A: Analyses conditional on limited attention

\begin{tabular}{|c|c|c|c|c|c|}
\hline \multirow[b]{3}{*}{ Variables } & & \multicolumn{2}{|c|}{$\begin{array}{c}\text { Concurrent earnings } \\
\text { announcement }\end{array}$} & \multicolumn{2}{|c|}{ Institutional ownership } \\
\hline & & Low & High & High & Low \\
\hline & & (1) & $(2)$ & (3) & (4) \\
\hline \multirow[t]{2}{*}{ QSUE } & & $0.0266 * * *$ & $0.0364 * * *$ & $0.0218 * * *$ & $0.0356 * * *$ \\
\hline & & $(3.53)$ & $(5.19)$ & $(2.77)$ & $(3.91)$ \\
\hline \multirow[t]{2}{*}{ POST $\times Q S U E$} & (A) & 0.0013 & 0.0114 & 0.0106 & 0.0028 \\
\hline & & $(0.26)$ & $(\mathbf{1 . 3 1})$ & $(\mathbf{1 . 5 5 )}$ & $(0.28)$ \\
\hline \multirow[t]{2}{*}{ POST $\times$ Treatment } & & 0.0148 & 0.0013 & 0.0224 & 0.0054 \\
\hline & & $(1.17)$ & $(0.10)$ & $(1.62)$ & $(0.51)$ \\
\hline \multirow[t]{2}{*}{ QSUE×Treatment } & & 0.0174 & -0.0175 & 0.0213 & -0.0144 \\
\hline & & $(1.26)$ & $(-1.69)$ & $(1.61)$ & $(-0.81)$ \\
\hline \multirow[t]{2}{*}{ POST $\times$ QSUE $\times$ Treatment } & (B) & $-0.0525 * * *$ & $-0.0276 *$ & $-0.0552 * * *$ & -0.0182 \\
\hline & & $(-3.71)$ & $(-1.94)$ & $(-3.87)$ & $(-0.93)$ \\
\hline $\operatorname{Low}(A+B)=\operatorname{High}(A+B)$ & & \multicolumn{2}{|c|}{$\chi^{2}=5.64$} & \multicolumn{2}{|c|}{$\chi=3.87^{\dagger t}$} \\
\hline Control variables & & \multicolumn{4}{|c|}{ Yes } \\
\hline Fixed effects & & \multicolumn{4}{|c|}{ Country, industry, year } \\
\hline No. of obs. & & 10,629 & 10,491 & 9,302 & 9,250 \\
\hline Adj. $R^{2}$ & & 0.05 & 0.05 & 0.05 & 0.04 \\
\hline
\end{tabular}

Panel B: Analysis conditional on firm-level limits to arbitrage

\begin{tabular}{|c|c|c|c|c|c|}
\hline \multirow{3}{*}{ Variables } & & \multicolumn{2}{|c|}{ Amihud illiquidity } & \multicolumn{2}{|c|}{ Idiosyncratic volatility } \\
\hline & & Low & High & Low & High \\
\hline & & (1) & (2) & (3) & (4) \\
\hline QSUE & & $\begin{array}{l}0.0261 * * * \\
(3.66)\end{array}$ & $\begin{array}{l}0.0397 * * * \\
(4.32)\end{array}$ & $\begin{array}{l}0.0287 \text { *** } \\
(8.06)\end{array}$ & $\begin{array}{l}0.0331 * * * \\
(3.18)\end{array}$ \\
\hline POST $\times Q S U E$ & (A) & $\begin{array}{l}-0.0033 \\
(-0.98)\end{array}$ & $\begin{array}{l}0.0110 \\
(0.98)\end{array}$ & $\begin{array}{l}-0.0042 \\
(-0.59)\end{array}$ & $\begin{array}{l}0.0126 \\
(1.18)\end{array}$ \\
\hline POST $\times$ Treatment & & $\begin{array}{l}0.0141 \\
(1.45)\end{array}$ & $\begin{array}{l}0.0065 \\
(0.53)\end{array}$ & $\begin{array}{l}0.0213^{*} \\
(1.76)\end{array}$ & $\begin{array}{l}-0.0035 \\
(-0.29)\end{array}$ \\
\hline QSUE×Treatment & & $\begin{array}{l}0.0070 \\
(0.64)\end{array}$ & $\begin{array}{l}-0.0112 \\
(-0.76)\end{array}$ & $\begin{array}{l}0.0181 * \\
(1.74)\end{array}$ & $\begin{array}{l}-0.0156 \\
(-1.01)\end{array}$ \\
\hline POST $\times$ QSUE $\times$ Treatment & (B) & $\begin{array}{c}-0.0462 * * * \\
(-3.71)\end{array}$ & $\begin{array}{l}-0.0243 * * \\
(-2.10)\end{array}$ & $\begin{array}{l}-0.0450 * * * \\
(-3.69)\end{array}$ & $\begin{array}{l}-0.0253 \\
(-1.36)\end{array}$ \\
\hline $\operatorname{Low}(A+B)=\operatorname{High}(A+B)$ & & \multicolumn{2}{|c|}{$\chi^{2}=4.11 \dagger \dagger$} & \multicolumn{2}{|c|}{$\chi^{2}=4.69 \dagger \dagger$} \\
\hline Control variables & & \multicolumn{4}{|c|}{ Yes } \\
\hline Fixed effects & & \multicolumn{4}{|c|}{ Country, industry, year } \\
\hline No. of obs. & & 10,537 & 10,583 & 10,537 & 10,583 \\
\hline Adj. $\mathrm{R}^{2}$ & & 0.06 & 0.04 & 0.07 & 0.04 \\
\hline
\end{tabular}


Table 6

Continued

Panel C: The joint effect of limited attention and limits of arbitrage

\begin{tabular}{|c|c|c|c|c|c|c|c|}
\hline \multirow{2}{*}{$\begin{array}{l}\text { Samples split by } \\
\text { Limits to arbitrage }\end{array}$} & \multirow[t]{2}{*}{$\begin{array}{c}\text { Sum of coeff. on } \\
\text { POST } \times Q S U E \text { and } \\
\text { POST } \times Q S U E \\
\times T r e a t m e n t \\
\end{array}$} & \multicolumn{3}{|c|}{ Concurrent earnings announcement } & \multicolumn{3}{|c|}{ Institutional ownership } \\
\hline & & $\begin{array}{l}\begin{array}{l}\text { Low } \\
(1)\end{array} \\
\end{array}$ & $\begin{array}{c}\text { High } \\
(2)\end{array}$ & $\begin{array}{c}\text { Differences } \\
(3)\end{array}$ & $\begin{array}{l}\text { High } \\
(\mathbf{4})\end{array}$ & $\begin{array}{l}\text { Low } \\
(5)\end{array}$ & $\begin{array}{c}\text { Differences } \\
(6)\end{array}$ \\
\hline \multirow{3}{*}{ Amihud illiquidity } & Low & $-0.0808 * * *$ & -0.0222 & $\chi^{2}=4.14 \dagger \dagger$ & $-0.0519 * * *$ & -0.0254 & $\chi^{2}=2.88 \dagger \dagger$ \\
\hline & High & $-0.0344 *$ & -0.0144 & $\chi 2=0.16$ & -0.0335 & -0.0011 & $\chi 2=0.07$ \\
\hline & Differences & $\chi^{2}=3.51 \dagger \dagger$ & $\chi^{2}=0.08$ & & $\chi^{2}=0.48$ & $\chi^{2}=0.71$ & \\
\hline \multirow{3}{*}{ Idiosyncratic volatility } & Low & $-0.0535 * * *$ & $-0.0483 * *$ & $\chi^{2}=0.05$ & $-0.0527 * * *$ & $-0.0517 * * *$ & $\chi^{2}=0.02$ \\
\hline & High & $-0.0477 * * *$ & -0.0113 & $\chi^{2}=5.90 \dagger \dagger$ & $-0.0358 *$ & 0.0075 & $\chi^{2}=4.01 \dagger \dagger$ \\
\hline & Differences & $\chi 2=0.08$ & $\chi^{2}=3.41+\dagger$ & & $\chi^{2}=0.41$ & $\chi 2=3.87+\dagger$ & \\
\hline
\end{tabular}

This table shows the effects of information shock on post-earnings-announcement drift, conditional on limited attention and limits to arbitrage. Panel A reports the effects of information shock on PEAD, conditional on distraction effects and investor sophistication, measured by of the number of concurrent earnings announcements and institutional ownership, respectively. Panel B reports the effects of information shock on PEAD, conditional on transaction costs and arbitrage risks, measured by Amihud (2002) illiquidity and idiosyncratic volatility, respectively. Panels C reports the effects of information shock on PEAD, conditional on the joint effects of limited attention and limits to arbitrage. The dependent variable is POSTRET. See Appendix B for definitions of variables. ***, **, and * indicate that the coefficient estimates are significant at the 1\%,5\%, and 10\% levels (two-tailed), respectively. $\%$ indicates that the difference in coefficient estimates between subsamples (i.e., $\chi^{2}$ ) is significant at the $5 \%$ level (one-tailed). 
Table 7

The role of country-level institutions

Panel A: Analysis conditional on country-level institutional factors

\begin{tabular}{|c|c|c|c|c|c|c|c|}
\hline \multirow[b]{3}{*}{ Variables } & & \multicolumn{2}{|c|}{ Capital market development } & \multicolumn{2}{|c|}{ Rule of law } & \multicolumn{2}{|c|}{ Earnings management } \\
\hline & & High & Low & High & Low & Low & High \\
\hline & & (1) & $(2)$ & (3) & (4) & (5) & (6) \\
\hline QSUE & & $\begin{array}{l}0.0344 * * * \\
(3.63)\end{array}$ & $\begin{array}{l}0.0034 \\
(0.26)\end{array}$ & $\begin{array}{l}0.0322 * * * \\
(3.57)\end{array}$ & $\begin{array}{l}0.0267 * \\
(1.80)\end{array}$ & $\begin{array}{l}0.0297 * * * \\
(3.41)\end{array}$ & $\begin{array}{l}0.0348 * * * \\
(3.04)\end{array}$ \\
\hline POST×QSUE & (A) & $\begin{array}{l}\mathbf{0 . 0 0 4 0} \\
(\mathbf{0 . 7 0})\end{array}$ & $\begin{array}{l}0.0275 * * \\
(2.11)\end{array}$ & $\begin{array}{l}\mathbf{0 . 0 0 5 0} \\
(0.94)\end{array}$ & $\begin{array}{l}0.0141 \\
(0.90)\end{array}$ & $\begin{array}{l}\mathbf{0 . 0 0 7 3} \\
(\mathbf{1 . 6 4 )}\end{array}$ & $\begin{array}{l}0.0005 \\
(0.07)\end{array}$ \\
\hline POST $\times$ Treatment & & 0.0022 & 0.0305 & 0.0086 & 0.0097 & 0.0023 & 0.0222 \\
\hline QSUExTreatment & & $\begin{array}{l}(0.19) \\
-0.0011 \\
(-0.07)\end{array}$ & $\begin{array}{l}(1.30) \\
0.0232 \\
(1.42)\end{array}$ & $\begin{array}{l}(0.74) \\
-0.0019 \\
(-0.14)\end{array}$ & $\begin{array}{l}(0.53) \\
0.0039 \\
(0.18)\end{array}$ & $\begin{array}{l}(0.19) \\
0.0069 \\
(0.48)\end{array}$ & $\begin{array}{l}(1.50) \\
-0.0128 \\
(-0.92)\end{array}$ \\
\hline POST $\times Q S U E \times$ Treatment & (B) & $\begin{array}{l}-0.0415 * * * \\
(-3.47)\end{array}$ & $\begin{array}{l}-0.0412 * \\
(-1.71)\end{array}$ & $\begin{array}{l}-0.0382 * * * \\
(-3.26)\end{array}$ & $\begin{array}{l}-0.0269 \\
(-0.94)\end{array}$ & $\begin{array}{l}-0.0487 * * * \\
(-3.96)\end{array}$ & $\begin{array}{l}-0.0103 \\
(-0.70)\end{array}$ \\
\hline $\operatorname{Low}(A+B)=\operatorname{High}(A+B)$ & & \multicolumn{2}{|c|}{$\chi^{2}=3.20^{\dagger \gamma}$} & \multicolumn{2}{|c|}{$\chi^{2}=\mathbf{2 . 7 4}$} & \multicolumn{2}{|c|}{$\chi^{2}=3.89$} \\
\hline Control variables & & \multicolumn{6}{|c|}{ Yes } \\
\hline Fixed effects & & \multicolumn{6}{|c|}{ Country, industry, year } \\
\hline No. of obs. & & 17,106 & 4,014 & 17,418 & 3,702 & 14,015 & 6,493 \\
\hline Adj. $\mathrm{R}^{2}$ & & 0.05 & 0.04 & 0.05 & 0.06 & 0.05 & 0.04 \\
\hline
\end{tabular}


Table 7, continued

Panel B: The joint effects of country-level capital market development and firm-level distraction effects/investor sophistication and limits-to-arbitrage

\begin{tabular}{|c|c|c|c|c|}
\hline Samples split by & $\begin{array}{c}\text { Sum of coeff. on } \\
\text { POST } \times \text { QSUE and } \\
\text { POST } \times \text { QSUE } \times \text { Treatment }\end{array}$ & $\begin{array}{l}\text { High capital } \\
\text { market } \\
\text { development }\end{array}$ & $\begin{array}{c}\text { Low capital } \\
\text { market } \\
\text { development }\end{array}$ & Differences \\
\hline & & (1) & $(2)$ & (3) \\
\hline \multirow{3}{*}{$\begin{array}{l}\text { Concurrent } \\
\text { earnings } \\
\text { announcements }\end{array}$} & Low & $-0.0628 * * *$ & -0.0289 & $\chi 2=4.27 \dagger \dagger$ \\
\hline & High & $-0.0238 * *$ & -0.0027 & $\chi^{2}=0.79$ \\
\hline & Diff. & $\chi 2=7.64 \dagger \dagger \dagger$ & $\chi^{2}=0.97$ & \\
\hline \multirow{3}{*}{$\begin{array}{l}\text { Institutional } \\
\text { ownership }\end{array}$} & High & $-0.0489 * * *$ & 0.0009 & $\chi^{2}=0.71$ \\
\hline & Low & -0.0259 & -0.0363 & $\chi 2=0.18$ \\
\hline & Diff. & $\chi 2=0.66$ & $\chi^{2}=2.36 \dagger$ & \\
\hline \multirow{3}{*}{$\begin{array}{l}\text { Amihud } \\
\text { illiquidity }\end{array}$} & Low & $-0.0410 * * *$ & $-0.0398 * *$ & $\chi^{2}=0.04$ \\
\hline & High & $-0.0350 * *$ & 0.0123 & $\chi^{2}=4.79 \dagger \dagger$ \\
\hline & Diff. & $\chi^{2}=0.06$ & $\chi 2=8.23+\dagger \dagger$ & \\
\hline \multirow{3}{*}{$\begin{array}{l}\text { Idiosyncratic } \\
\text { volatility }\end{array}$} & Low & $-0.0607 * * *$ & $-0.0295 *$ & $\chi 2=4.11+\dagger$ \\
\hline & High & -0.0184 & -0.0035 & $\chi 2=0.18$ \\
\hline & Diff. & $\chi 2=3.35 \dagger \dagger$ & $\chi 2=0.47$ & \\
\hline
\end{tabular}

This table shows the effects of information shock on PEAD, conditional on country-level institutions. Panel A reports the effects of information shock on PEAD, conditional on country-level capital market development, rule of law, and earnings management. Panel B reports the effects of information shock on PEAD, conditional on the joint effects of country-level capital market development and firm-level investor attention and limits to arbitrage. The dependent variable is POSTRET. See Appendix B for definitions of variables. ***, **, and * indicate that the coefficient estimates are significant at the 1\%,5\%, and $10 \%$ levels (two-tailed), respectively. $\%$ indicates that the difference in coefficient estimates between subsamples (i.e., $\chi^{2}$ ) is significant at the $5 \%$ level (one-tailed). 
Table 8

The effects of financial reporting changes, forecast accuracy, institutional holdings, and limits to arbitrage on changes in PEAD, treatment sample only

Panel A: Changes in financial reporting

\begin{tabular}{|c|c|c|c|c|c|c|}
\hline$F A C T O R=1$, if & $\triangle$ GAAP1=1 & $\triangle$ GAAP1 $_{\mathbf{B} / \mathbf{S}}=1$ & $\Delta$ GAAP1 $_{I / S}=1$ & $\triangle$ GAAP2=1 & $\triangle$ GAAP2 $2_{\mathrm{B} / \mathrm{S}}=1$ & $\Delta \mathbf{G A A P 2}_{\mathrm{I} / \mathrm{S}}=\mathbf{1}$ \\
\hline Variables & (1) & (2) & (3) & (4) & (5) & (6) \\
\hline \multirow[t]{2}{*}{ QSUE } & $0.0138 * *$ & $0.0179 * *$ & $0.0279 * * *$ & $0.0169 * *$ & $0.0194 *$ & $0.0160 *$ \\
\hline & $(2.47)$ & $(2.02)$ & $(3.85)$ & $(1.97)$ & $(2.03)$ & $(1.81)$ \\
\hline \multirow[t]{2}{*}{ POST×QSUE } & -0.0068 & -0.0146 & $-0.0229 * *$ & -0.0005 & -0.0021 & 0.0003 \\
\hline & $(-0.39)$ & $(-1.59)$ & $(-2.26)$ & $(-0.05)$ & $(-0.16)$ & $(0.03)$ \\
\hline \multirow[t]{2}{*}{ POST×FACTOR } & 0.0086 & -0.0051 & $0.0258 * *$ & 0.0094 & 0.0088 & 0.0124 \\
\hline & $(0.81)$ & $(-0.37)$ & $(2.51)$ & $(0.88)$ & $(0.94)$ & $(1.05)$ \\
\hline \multirow[t]{2}{*}{ QSUE×FACTOR } & $0.0169 * * *$ & 0.0125 & 0.0013 & 0.0108 & 0.0115 & 0.0153 \\
\hline & $(2.61)$ & $(1.54)$ & $(0.16)$ & $(1.14)$ & $(1.13)$ & $(1.53)$ \\
\hline \multirow[t]{2}{*}{ POST $\times Q S U E \times F A C T O R$} & $-0.0248 *$ & $-0.0132 * *$ & $-0.0355 *$ & $-0.0332 * * *$ & $-0.0336 * *$ & $-0.0351 * * *$ \\
\hline & $(-1.91)$ & $(-2.19)$ & $(-1.75)$ & $(-2.74)$ & $(-2.11)$ & $(-2.60)$ \\
\hline \multirow[t]{2}{*}{ SIZE } & $0.0043 * * *$ & $0.0044 * * *$ & $0.0045^{* * *}$ & $0.0043 * * *$ & $0.0045^{* * *}$ & $0.0046 * * *$ \\
\hline & $(2.94)$ & $(2.97)$ & $(3.10)$ & $(3.00)$ & $(3.18)$ & $(3.21)$ \\
\hline \multirow[t]{2}{*}{ МТB } & -0.0003 & -0.0003 & -0.0003 & -0.0003 & -0.0003 & -0.0003 \\
\hline & $(-0.69)$ & $(-0.71)$ & $(-0.75)$ & $(-0.71)$ & $(-0.75)$ & $(-0.75)$ \\
\hline \multirow[t]{2}{*}{ BETA } & $-0.0223 * * *$ & $-0.0219 * * *$ & $-0.0220 * * *$ & $-0.0231 * * *$ & $-0.0221 * * *$ & $-0.0223 * * *$ \\
\hline & $(-4.47)$ & $(-4.28)$ & $(-4.25)$ & $(-4.78)$ & $(-4.38)$ & $(-4.46)$ \\
\hline \multirow[t]{2}{*}{ PRERET } & $0.0390 * *$ & $0.0389 * *$ & $0.0386^{* *}$ & $0.0370 * * *$ & $0.0387 * *$ & $0.0387 * *$ \\
\hline & $(2.57)$ & $(2.56)$ & $(2.50)$ & $(2.66)$ & $(2.54)$ & $(2.53)$ \\
\hline Fixed effects & \multicolumn{6}{|c|}{ Country, industry, year } \\
\hline No. of obs. & 6,862 & 6,862 & 6,862 & 6,551 & 6,551 & 6,551 \\
\hline Adj. $\mathrm{R}^{2}$ & 0.05 & 0.05 & 0.05 & 0.05 & 0.05 & 0.05 \\
\hline
\end{tabular}


Table 8, continued

Panel B: Changes in forecast accuracy, institutional ownership, and limits to arbitrage

\begin{tabular}{|c|c|c|c|c|}
\hline Factor $=1$ if & $\Delta \mid$ FERROR $\mid<0$ & $\Delta \mathbf{I N S T}>\mathbf{0}$ & $\Delta$ ILLIQ $<0$ & $\Delta \mathrm{IVOL}<\mathbf{0}$ \\
\hline Variables & (1) & $(2)$ & (3) & (4) \\
\hline \multirow[t]{2}{*}{ QSUE } & $0.0249 * *$ & 0.0151 & $-0.0214 * * *$ & 0.0089 \\
\hline & $(2.23)$ & $(1.50)$ & $(-3.25)$ & $(1.48)$ \\
\hline \multirow[t]{2}{*}{ POST×QSUE } & $-0.0207 *$ & 0.0070 & 0.0097 & -0.0132 \\
\hline & $(-1.76)$ & $(0.38)$ & $(0.49)$ & $(-1.07)$ \\
\hline \multirow[t]{2}{*}{ POST×FACTOR } & $0.0239 * * *$ & 0.0157 & 0.0176 & -0.0076 \\
\hline & $(2.71)$ & $(1.27)$ & $(1.68)$ & $(-0.62)$ \\
\hline \multirow[t]{2}{*}{ QSUE×FACTOR } & 0.0041 & 0.0156 & $0.0591 * * *$ & $0.0380 * * *$ \\
\hline & $(0.52)$ & $(1.28)$ & $(7.66)$ & $(3.84)$ \\
\hline \multirow[t]{2}{*}{ POST $\times$ QSUE $\times$ FACTOR } & $-0.0104 *$ & $-0.0415 * *$ & $-0.0444 * *$ & $-0.0288 * *$ \\
\hline & $(-1.93)$ & $(-1.97)$ & $(-2.21)$ & $(-2.06)$ \\
\hline \multirow[t]{2}{*}{ SIZE } & $0.0041 * * *$ & $0.0045^{* * *}$ & $0.0034 * *$ & $0.0043 * * *$ \\
\hline & (2.94) & $(3.24)$ & $(2.29)$ & $(3.03)$ \\
\hline \multirow[t]{2}{*}{ MTB } & -0.0003 & -0.0003 & -0.0003 & -0.0002 \\
\hline & $(-0.96)$ & $(-0.75)$ & $(-0.70)$ & $(-0.66)$ \\
\hline \multirow[t]{2}{*}{ BETA } & $-0.0237 * * *$ & $-0.0220 * * *$ & $-0.0248 * * *$ & $-0.0182 * * *$ \\
\hline & $(-4.80)$ & $(-4.24)$ & $(-5.08)$ & $(-3.36)$ \\
\hline \multirow[t]{2}{*}{ PRERET } & $0.0363 * *$ & $0.0379 * *$ & $0.0328^{* *}$ & $0.0412 * * *$ \\
\hline & $(2.30)$ & $(2.55)$ & $(2.15)$ & $(2.71)$ \\
\hline Fixed effects & \multicolumn{4}{|c|}{ Country, industry, year } \\
\hline No. of obs. & 6,862 & 6,862 & 6,862 & 6,862 \\
\hline Adj. $R^{2}$ & 0.05 & 0.05 & 0.06 & 0.06 \\
\hline
\end{tabular}

This table examines the channels through which the information shock affects PEAD. Panel A reports the effects of financial reporting changes on PEAD. Panel B reports changes in analyst earnings forecast accuracy, institutional holdings and limits to arbitrage on changes in PEAD. The dependent variable is POSTRET. FACTOR is a dummy variable set to one if a treatment firm experiences a greater financial reporting change (High $\triangle$ GAAP), an improvement in analyst forecast accuracy $(\Delta \mid$ FERROR $\mid<0)$, an increase in institutional holdings $(\Delta \mathrm{INST}>0)$, a decrease in Amihud illiquidity $(\Delta \mathrm{ILLIQ}<0)$ or a decrease in idiosyncratic volatility $(\Delta \mathrm{IVOL}<0)$ after the information shock, and zero otherwise. See Appendix B for definitions of variables. Robust $t$-statistics adjusted for country clusters are reported in parentheses. $* * *, * *$, and * indicate significance at the $1 \%, 5 \%$, and $10 \%$ levels (two-tailed), respectively. 
Table 9

The effect of information shock on the proportion of the total stock market reaction to earnings announcement attributable to drift

Panel A: Analysis of the proportionate drift, average effects

\begin{tabular}{|c|c|c|c|c|c|}
\hline \multirow[b]{3}{*}{ Variables } & & \multicolumn{2}{|c|}{ Treatment sample } & \multicolumn{2}{|c|}{ Full sample } \\
\hline & & CAR[-1,1] & $\mathrm{CAR}[2,64]$ & CAR[-1,1] & $\operatorname{CAR}[2,64]$ \\
\hline & & (1) & (2) & (3) & $(4)$ \\
\hline \multirow[t]{2}{*}{ QSUE } & $\mathrm{a}$ & $0.0195 * * *$ & $0.0281 * * *$ & $0.0326 * * *$ & $0.0312 * * *$ \\
\hline & & $(7.10)$ & $(4.34)$ & $(3.61)$ & $(4.15)$ \\
\hline \multirow[t]{2}{*}{ POST×QSUE } & $\mathrm{b}$ & -0.0027 & $-0.0275 * * *$ & $0.0086^{* * *}$ & 0.0063 \\
\hline & & $(-0.88)$ & $(-3.11)$ & $(6.12)$ & $(1.36)$ \\
\hline \multirow[t]{2}{*}{ POST $\times$ Treatment } & & & & 0.0029 & 0.0086 \\
\hline & & & & $(1.61)$ & $(0.87)$ \\
\hline \multirow[t]{2}{*}{ QSUExTreatment } & $\mathrm{c}$ & & & -0.0135 & -0.0015 \\
\hline & & & & $(-1.39)$ & $(-0.13)$ \\
\hline \multirow[t]{2}{*}{ POST $\times$ QSUE $\times$ Treatment } & d & & & $-0.0111 * * *$ & $-0.0353 * * *$ \\
\hline & & & & $(-3.41)$ & $(-3.31)$ \\
\hline Control variables & & \multicolumn{4}{|c|}{ Yes } \\
\hline Fixed effects & & \multicolumn{4}{|c|}{ Country, industry, year } \\
\hline No. of obs. & & 6,862 & 6,862 & 21,120 & 21,120 \\
\hline Adj. $R^{2}$ & & 0.04 & 0.05 & 0.05 & 0.04 \\
\hline \multicolumn{6}{|l|}{ Change of proportionate drift } \\
\hline \multicolumn{6}{|c|}{ Formula for calculating proportionate drift } \\
\hline \multicolumn{6}{|c|}{ Treatment sample } \\
\hline (2a) $/(1 a+2 a) \quad$ in pre-period & & $58.99 \%$ & & & \\
\hline$(2 a+2 b) /(1 a+1 b+2 a+2 b)$ in post-period & & $3.43 \%$ & & & \\
\hline$(4 a+4 c) /(3 a+4 a+3 c+4 c)$ in pre-adoption & & & & $60.77 \%$ & \\
\hline \multicolumn{2}{|c|}{$(4 a+4 b+4 c+4 d) /(3 a+4 a+3 b+4 b+3 c+4 c+3 d+4 d)$} & & & $435 \%$ & \\
\hline \multicolumn{2}{|c|}{ in post-adoption period } & & & 4.5510 & \\
\hline Diff. between pre- and post- period & & $\chi^{2}=\mathbf{2 . 8 2}$ & & $\chi^{2}=3.31$ & \\
\hline \multicolumn{6}{|l|}{ Benchmark sample } \\
\hline$(4 a) /(3 a+4 a)$ & & & & $48.90 \%$ & \\
\hline$(4 a+4 b) /(3 a+4 a+3 b+4 b)$ in post-adopti & & & & $47.72 \%$ & \\
\hline Diff. between pre- and post- period & & & & $\chi^{2}=0.06$ & \\
\hline
\end{tabular}


Table 9, continued

Panel B: Analysis conditional on Friday vs. non-Friday earnings announcements

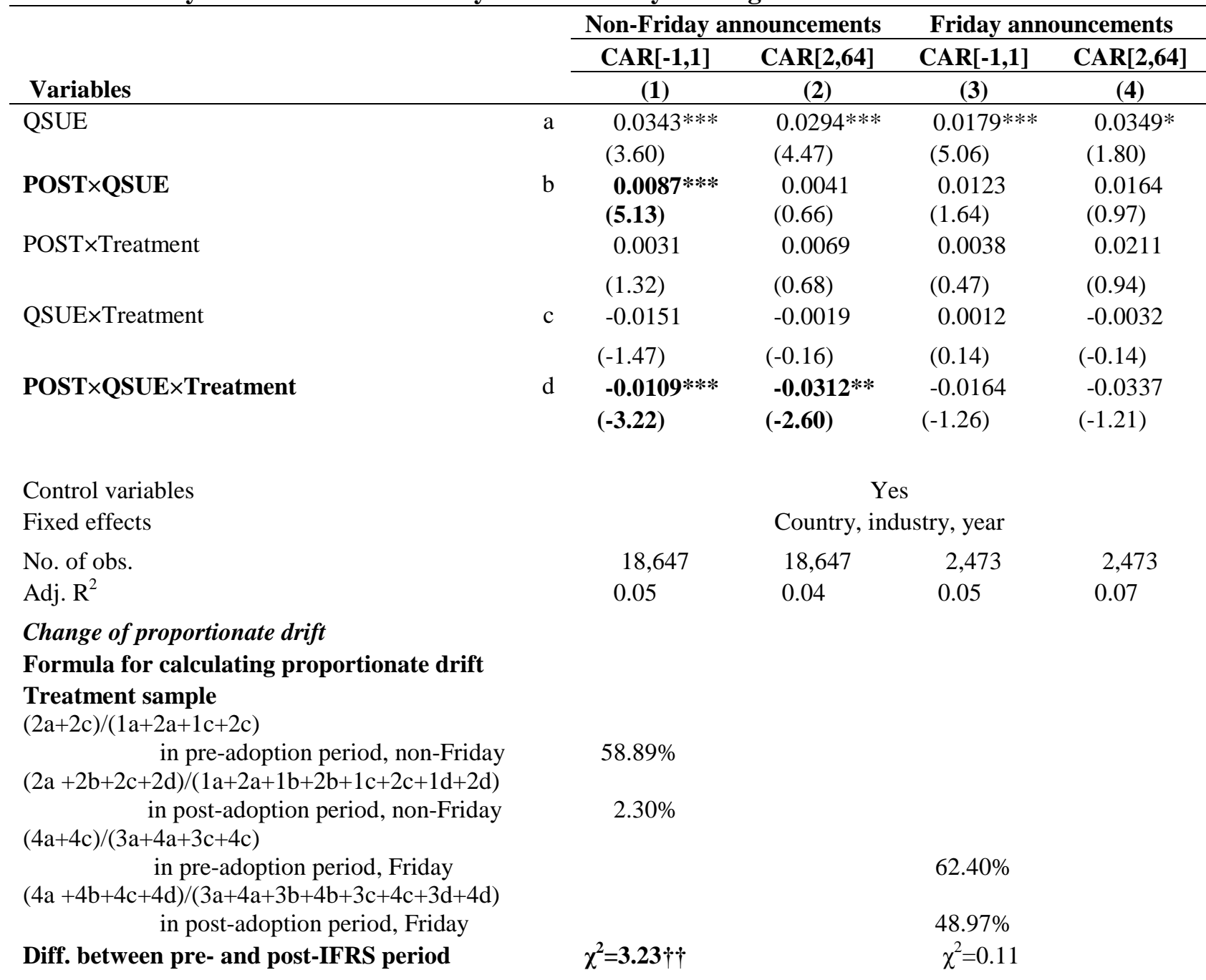

\section{Benchmark sample}

$(2 a) /(1 a+2 a)$ in pre-adoption period, non-Friday

$46.15 \%$

$(2 a+2 b) /(1 a+2 a+1 b+2 b)$

in pre-adoption period, non-Friday

$43.79 \%$

$(4 a) /(3 a+4 a)$ in post-adoption period, Friday

$(4 a+4 b) /(3 a+4 a+3 b+4 b)$

in post-adoption period, Friday

Diff. between pre- and post-IFRS period

\begin{tabular}{c}
$66.10 \%$ \\
$62.94 \%$ \\
$\chi^{2}=0.16 \quad \chi^{2}=0.10$ \\
\hline
\end{tabular}

This table presents market reactions to earnings surprises during earnings-announcement period $[-1,1]$ and postearnings-announcement period [2,64]. Panel A reports the full sample analysis. Panel B reports market reactions to Friday earnings announcements and non-Friday earnings announcements. Dependent variables are buy-and-hold abnormal returns during earnings-announcement period [-1, 1] in Columns (1) and (3) and post-earningsannouncement period [2, 64] in Columns (2) and (4). See Appendix B for variable definitions. Robust $t$-statistics adjusted for country clusters are reported in parentheses. $* * *, * * *$ indicate significance at the $1 \%, 5 \%$ and $10 \%$ levels (two-tailed), respectively. ${ }^{\prime \prime}$ indicate that $\chi^{2}$ is significant at the $5 \%$ level (one-tailed). 
Table 10

Serial correlation in analyst forecast errors after the information shock

\begin{tabular}{lcc}
\hline & Treatment sample & Full sample \\
\cline { 2 - 3 } Variables & $(\mathbf{1})$ & $(\mathbf{2})$ \\
\hline $\mathrm{FE}_{\mathrm{t}}$ & $0.4968^{* * *}$ & $0.2526^{* * *}$ \\
$\mathbf{F E}_{\mathrm{t}} \times \mathbf{P O S T}$ & $(7.14)$ & $(3.65)$ \\
& -0.1239 & $0.7679 * * *$ \\
POST $\times$ Treatment & $(-0.85)$ & $(3.32)$ \\
& & 0.0026 \\
$\mathrm{FE}_{\mathrm{t}} \times$ Treatment & & $(0.80)$ \\
& & $0.2703^{* * *}$ \\
$\mathbf{F E}_{\mathrm{t}} \times \mathbf{P O S T} \times$ Treatment & & $(2.70)$ \\
& & $\mathbf{- 0 . 8 9 6 6 * * *}$ \\
Fixed effects & & $\mathbf{- 3 . 3 0 )}$ \\
No. of obs. & Country, industry, year & \\
Adj. $\mathrm{R}^{2}$ & 6,228 & 19,264 \\
\hline
\end{tabular}

This table shows the effects of the information shock on the serial correlation in analyst forecast errors. The dependent variable is $F E_{\mathrm{t}+1}$. See Appendix B for definitions of variables. Robust $t$-statistics adjusted for country clusters are reported in parentheses. ***,**, $*$ indicate significance at the $1 \%, 5 \%$ and $10 \%$ levels (two-tailed), respectively. 
Table 11

The effect of the information shock on other anomalies

\begin{tabular}{|c|c|c|c|c|c|}
\hline \multicolumn{2}{|c|}{ Earnings announcement premium } & \multicolumn{2}{|c|}{ Return momentum } & \multicolumn{2}{|c|}{ Short-term return reversal } \\
\hline Variables & Coeff. & Variables & Coeff. & Variables & Coeff. \\
\hline & (1) & & (2) & & (3) \\
\hline ExpAnn & $\begin{array}{l}-0.0072 \\
(-1.06)\end{array}$ & Lag return & $\begin{array}{l}\text { 0.0778*** } \\
(3.62)\end{array}$ & Lag return & $\begin{array}{l}0.0120 \\
(1.09)\end{array}$ \\
\hline ExpAnn×Post & $\begin{array}{l}0.0077 * * * \\
(2.71)\end{array}$ & Lag return $\times$ Post & $\begin{array}{l}0.0164 \\
(0.66)\end{array}$ & Lag return $\times$ Post & $\begin{array}{l}-0.0022 * * \\
(-2.23)\end{array}$ \\
\hline PostxTreatment & $\begin{array}{l}0.0041 \\
(0.82)\end{array}$ & PostxTreatment & $\begin{array}{l}0.0113 \\
(0.37)\end{array}$ & PostxTreatment & $\begin{array}{l}-0.0025 \\
(-1.02)\end{array}$ \\
\hline ExpAnn×Treatment & $\begin{array}{l}0.0123 * * \\
(2.47)\end{array}$ & Lag return $\times$ Treatment & $\begin{array}{l}-0.0202 \\
(-0.92)\end{array}$ & Lag return $\times$ Treatment & $\begin{array}{l}-0.0027 * * \\
(-2.05)\end{array}$ \\
\hline $\begin{array}{l}\text { ExpAnn } \times \text { Post } \times \\
\text { Treatment }\end{array}$ & $\begin{array}{l}-0.0069 * * \\
(-2.32)\end{array}$ & $\begin{array}{l}\text { Lag return } \times \text { Post } \times \\
\text { Treatment }\end{array}$ & $\begin{array}{l}-0.0151 \\
(-0.58)\end{array}$ & $\begin{array}{l}\text { Lag return } \times \text { Post } \times \\
\text { Treatment }\end{array}$ & $\begin{array}{l}0.0033 \\
(1.44)\end{array}$ \\
\hline SIZE & $\begin{array}{l}0.0020 * * * \\
(4.40)\end{array}$ & SIZE & $\begin{array}{l}0.0053 * * \\
(2.40)\end{array}$ & SIZE & $\begin{array}{l}0.0006 * * * \\
(3.65)\end{array}$ \\
\hline BTM & $\begin{array}{l}0.0097 * * * \\
(5.15)\end{array}$ & ВТМ & $\begin{array}{l}0.0548 * * * \\
(8.87)\end{array}$ & BTM & $\begin{array}{l}0.0022 * * * \\
(6.40)\end{array}$ \\
\hline Market Return & $\begin{array}{l}0.8361 * * * \\
(7.53)\end{array}$ & Market Return & $\begin{array}{l}0.9587 * * * \\
(11.36)\end{array}$ & Market Return & $\begin{array}{l}0.6770 * * * \\
(9.23)\end{array}$ \\
\hline Lag Return & $\begin{array}{l}0.0119 * * * \\
(3.77)\end{array}$ & BETA & $\begin{array}{l}-0.0194 * * * \\
(-3.59)\end{array}$ & & \\
\hline Fixed effects & Country, Industry, Month & Fixed effects & Country, Industry, Month & Fixed effects & Country, Industry, Week \\
\hline Standard errors cluster & Country, Month & Standard errors cluster & Country, Month & Standard errors cluster & Country, Week \\
\hline No. obs. & 860,866 firm-months & No. obs. & 920,132 firm-months & No. obs. & 3,135,583 firm-weeks \\
\hline Adj. $R^{2}$ & 0.18 & Adj. $\mathrm{R}^{2}$ & 0.31 & Adj. $R^{2}$ & 0.12 \\
\hline $\begin{array}{l}\text { This table reports the im } \\
\text { of column (1) is the nat } \\
\text { expected to announce ar } \\
\text { month }[\mathrm{t}, \mathrm{t}+5] \text {. Lag retu } \\
\text { Lag return is further sca } \\
\text { column (3) is the scaled } \\
\text { two-year period after th } \\
\text { reported in parentheses } \\
\text { significance at the } 1 \%, 5\end{array}$ & $\begin{array}{l}\text { Dact of the information shock } \\
\text { ral log of one plus the raw re } \\
\text { nual earnings during month } t \\
n \text { in column (2) is the quintil } \\
\text { ed to be between zero and on } \\
\text { quintile rank (ranging from z } \\
\text { information shock and zero } \\
\text { Columns (1)-(2). Robust } t \text { - } \\
\% \text { and } 10 \% \text { levels (two-tailec }\end{array}$ & $\begin{array}{l}\text { on the earnings announce } \\
\text { urn for firm } i \text { in country } j \\
\text { The dependent variable o } \\
\text { rank of six-month buy-ar } \\
\text { e. The dependent variable } \\
\text { ro to one) of weekly retur } \\
\text { or the two-year period be } \\
\text { tatistics clustered by coun } \\
\text {, respectively. }\end{array}$ & $\begin{array}{l}\text { ent premium, return mome } \\
\text { uring month } t \text {. ExpAnn is a } \\
\text { column (2) is the six-month } \\
\text {-hold return of firm } i \text { in cou } \\
\text { f column (3) is the raw retu } \\
\text { of firm } i \text { in country } j \text { during } \\
\text { re the information shock. R } \\
\text { y and week are reported in }\end{array}$ & $\begin{array}{l}\text { tum, and short-term rever } \\
\text { indicator equal to one if } \\
\text { buy-and-hold return of fir } \\
\text { try } j \text { during month [t-7, } \mathrm{t} \text { - } \\
\mathrm{n} \text { for firm } i \text { in country } j \mathrm{~d} \\
\text { week } t-2 . P O S T \text { is an ind } \\
\text { bust } t \text {-statistics clustered } \\
\text { arentheses in Columns ( } 3\end{array}$ & $\begin{array}{l}\text { al. The dependent variable } \\
\text { rm } i \text { in country } j \text { is } \\
i \text { in country } j \text { during } \\
\text { ]. The quintile rank of } \\
\text { ing week } t \text {. Lag return in } \\
\text { ator equal to one for the } \\
\text { y country and month are } \\
* * *, * *, * \text { indicate }\end{array}$ \\
\hline
\end{tabular}




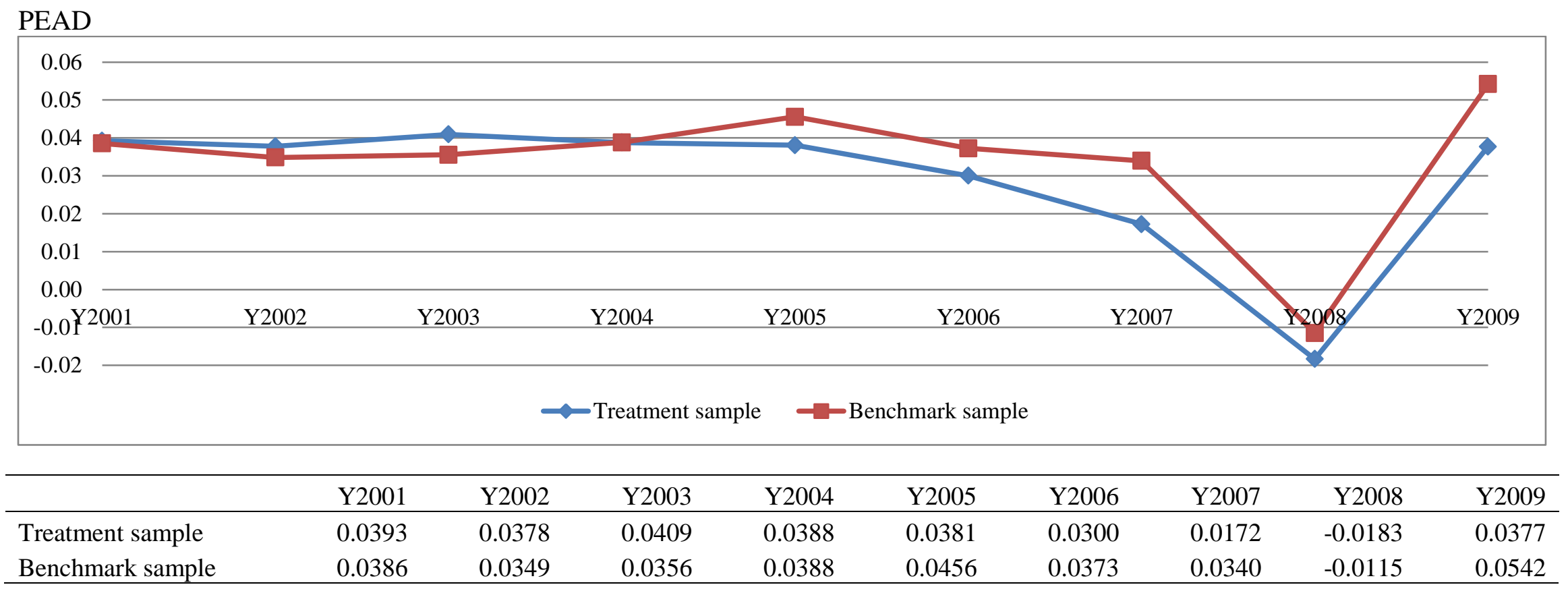

\section{Figure 1}

\section{Time-series of PEAD of sample countries from 2001 to 2009}

This figure presents the annual numbers of PEAD (post-earnings-announcement drift) over 30 sample countries from 2001 to 2009 . PEAD of every country-year is measured by the differences in the mean POSTRET of firms in the top quintile and firms in the bottom quintile of earnings surprises. POSTRET is measured by three-month (+2 to +64 trading days following the announcement) buy-and-hold return adjusted for contemporaneous buy-and-hold value-weighted market index return after the earnings announcement. The earnings surprise for each firm-year is calculated as actual earnings per share minus the last analyst consensus at least three days before the earnings announcement, scaled by the stock price at least six but not more than 12 days prior to the earnings announcement. 